\title{
Under-representation of faults on geological maps of the London region: reasons, consequences and solutions
}

D T Aldiss

British Geological Survey, Keyworth, Nottingham, NG12 5GG, UK

Corresponding author (e-mail: dta@bgs.ac.uk)

Running title: Under-represented faulting in the London region

Keywords: London; faulting; geological mapping methods; 3D geological model; Quaternary; neotectonics

\begin{abstract}
London lies mainly within an area of long-term tectonic stability known as the London Platform. This is characterised by relatively thin Cretaceous and Palaeogene sequences overlying Palaeozoic basement at shallow depths, less seismic activity than surrounding areas and, according to published geological maps, little faulting.

However, observations of temporary exposures and borehole records, and other studies, show that in reality faults are numerous and widespread in the London region. Their relative absence on the geological maps is a consequence of past mapping methods, coupled with the relative uniformity of extensive bedrock units such as the London Clay Formation and the Chalk Group, and the widespread presence of Quaternary and anthropogenic deposits, and of urban development. However, complementary approaches to geological surveying, including the use of geophysical data and satellite-based radar interferometry, together with geological modelling in three dimensions using subsurface information, provide the means to accurately survey fault systems even in the most densely urbanised areas.

Such work shows that earth movements in the London area, apparently including nearsurface fault displacements, have taken place during the late Quaternary and continue at the present. These findings are important to civil engineering projects and hydrogeological studies in the London area and to understanding local tectonic development.
\end{abstract}




\section{Introduction}

The megacity of London, UK, lies on the southern edge of the London Platform (the western part of the Anglo-Brabant Massif), an area of crustal stability during the Mesozoic and Cenozoic (Brenchley and Rawson, 2006). The western portion is underlain by part of the Midlands Microcraton, which has been largely stable since the Proterozoic, and the eastern part is founded on a buried north-west to south-east trending Caledonide fold belt, apparently largely stable since the mid-Palaeozoic (Fig. 1). In marked contrast, the Weald Basin, to the south, is founded on an east-west trending Variscan orogenic belt, which underwent crustal extension and subsidence during the Mesozoic, followed by inversion dating from the midCretaceous until the Miocene (Chadwick, 1993; Pharaoh et al., 1993; Busby and Smith, 2001; Chadwick and Evans, 2005). In the Weald Basin, folded and thrust Late Palaeozoic rocks are overlain by Permo-Triassic, Jurassic and Cretaceous successions exceeding $20 \mathrm{~km}$ in vertical thickness in places. In the core of the London Platform, Palaeozoic rocks occur at less than $350 \mathrm{~m}$ below the surface, overlain by relatively thin mid- to Late Cretaceous successions. Older Mesozoic strata were never deposited there, or were subsequently largely eroded. Those that remain within the London Platform have been interpreted as being preserved within inferred localised grabens, presumably formed by reactivation of older structures (Owen, 1971; Ellison et al., 2004). The London Platform was finally buried following marine transgression during the Albian (Rawson, 2006), but there is nevertheless still some difference in the thickness of the Late Cretaceous Chalk Group deposited on the London Platform and in the area of the Weald Basin, for example during the Cenomanian (Rawson, 2006; Mortimore, 2011). Part of the regional variation in the thickness of the entire Chalk Group is due to differences in the extent of post-Cretaceous erosion, but a comparison of the interval between the base of the Chalk Group and the base of the Seaford Chalk (in the younger part of the sequence) shows that it increases from about $150 \mathrm{~m}$ in the London area (Ellison et al., 2004) to about $250 \mathrm{~m}$ in the Lewes district of the South Downs (Lake et al., 1987).

Rifting and crustal extension occurred in the North Sea from the mid-Cretaceous onwards through the Cenozoic. In the southern North Sea, extending north-eastwards from the area of Figure1, the Chalk Group is thicker and was deposited for longer, into the Palaeocene, than on the London Platform (Downing et al., 1993; Rawson, 2006). Although parts of the London Platform experienced a series of marine transgressions during the Palaeogene, forming the deposits of the London Basin (Fig. 2), the onshore successions are thinner and less complete than those offshore, reflecting their position on the basin margin (Knox, 1996; King, 2006).

The perception that the London Platform is an area of very long-term tectonic stability is supported by the apparent sparseness of faults in the area, as shown by medium-scale geological maps (Fig. 2). To the north of the glacial limit (Fig. 2), faults that might be present in the bedrock are likely to be difficult to recognise by conventional field geological mapping methods due to the extensive cover of Quaternary deposits. However, even if that part of the London Platform is disregarded, the contrast in fault density with the Wealden area is striking. The principle exception is within the Wimbledon-Woolwich tectonic axis, where periclinal folding is accompanied by en echelon faulting (Ellison et al., 2004). It is likely, a 
priori, that the Palaeogene rifting in the southern North Sea extended south-westwards into the London Basin, cutting across the dominant structural fabric of the Caledonide basement, but very few faults within this system appear on BGS geological maps.

The same impression is conveyed by the distribution of recorded earthquakes in England and the surrounding offshore areas, which shows that much of central and south-east England, including the London Platform, experiences very little seismic activity (Fig. 3). Only three, historical, earthquakes are recorded from the London area, although these do include the Colchester earthquake of 1884, which is the most damaging earthquake in Britain so far recorded (Musson, 2007).

However, although the London Platform is an area of relative tectonic stability it is not devoid of past earth movement. As pointed out by Ellison et al. (2004) and by de Freitas (2009), for example, there is evidence of extensive faulting in London and the surrounding area. It appears that faults have been under-represented on the geological maps produced by the British Geological Survey (BGS) and its predecessors, the Institute of Geological Sciences and the Geological Survey of Great Britain. This paper examines the reasons for this having occurred, some of the kinds of evidence that demonstrate or imply the existence of faulting to the geological surveyor, and the means by which our knowledge of local fault patterns is now being improved. In addition, it presents evidence for some faulting having occurred at or very close to the surface in the area of central London during the later part of the Quaternary.

An accurate and representative map of fault distribution and patterns of displacement (amongst other structural elements, such as fold and joint patterns) is a pre-requisite for understanding the tectonic development of a region. Moreover, in the London area, there is evidence for some local tectonic control of Late Cretaceous sedimentation (Mortimore et al., 2011) and it is likely that similar control influenced local aspects of Palaeogene deposition (Ford et al., 2010). Aside from its scientific relevance, faulting is an important influence on the design and execution of civil engineering works, and on the hydrogeological characteristics of the ground (de Freitas, 2009; Newman, 2009; Newman et al., 2010). Indeed, many of the faults in London may not be simple planes of movement ('sharp deformation breaks with shearing displacement' in the sense of Gillespie et al., 2011), but rather have formed fault-zones, in which there may be an appreciable width of disturbed ground, perhaps with multiple planes of movement. Commonly, fault-zones contain weaker materials than the adjacent ground. Faults and fault-zones can juxtapose materials of different character, so giving rise to variable ground conditions. They can therefore add to the cost of civil engineering projects, especially if they have not been recognised at the design stage. Also, de Freitas (2009) argues that the geotechnical properties of an individual formation, such as the London Clay, are likely to vary from one fault block to an adjacent one. Faultzones can create flow paths for groundwater or barriers that confine its movement, or perhaps both. They can thereby add to hydrogeological anisotropy and to the consequent difficulties of managing resources of both groundwater and ground source heat, and of managing groundwater-related hazards such as variable ground pressures, formation de-gassing and rising water tables. Larger faults, with large vertical or lateral displacements, tend to be 
longer-lived and so, it is assumed, tend to be associated with broader and more complex zones of cataclasis, but even simple faults with small displacements can have significant implications for an engineering or a hydrogeological project. At the very least, faults may introduce difficulties to the interpretation of ground investigation boreholes or excavations.

\section{Evidence for faulting shown on geological maps}

Possible reasons why faulting might be consistently under-represented on geological maps produced by teams of experienced professional geological surveyors become apparent from a consideration of the methods by which the existence of a fault can be recognised and its extent determined, and of aspects of past BGS geological surveying practice. These remarks apply principally to areas of south-eastern England where the bedrock is very poorly exposed, but they can also apply, to some extent, to other parts of Britain, particularly where bedrock exposure is limited.

\subsection{Recognising faults in unexposed ground}

Faults can be observed directly where they occur in natural or artificial exposures, including core from boreholes. However, even if observation of an exposed fault plane gives some indication of the orientation of the fault-zone within which it lies, it is commonly not possible to determine the extent (in either width or length) or shape of that fault-zone beyond the edge of the exposure. Faults that are shown on geological maps are, mostly, those that can be traced through unexposed ground because they juxtapose different rock formations for a sufficient proportion of their outcrop. The contrast may be revealed by a change in soil type, or in the type of rock fragments to be found in the soil, or by an offset or other discontinuity in the topographic features that are associated with a particular geological unit (for example, a ridge or escarpment formed by a sandstone bed within a mudstone sequence).

Where faults in unexposed ground do not give rise to an observable compositional contrast over a sufficient distance, or where they do not offset distinctive marker horizons, they cannot be located by geological field survey alone. This situation can arise within broad outcrops of homogeneous units. Most of the London area, for example, is underlain by the London Clay Formation (Ellison et al., 2004). This unit is generally poorly exposed, with no topographic expression of the rather subtle compositional variations that occur within it. So faults that juxtapose different parts of the London Clay Formation give rise to no observable mappable contrasts. Moreover, large areas of the London Clay outcrop are covered by superficial deposits and anthropogenic deposits (made ground). Most faults that might be present in those areas are therefore difficult or impossible to map by conventional geological field survey methods.

This is acknowledged by Lake et al. (1986, p. 23), for example, who state 'Although a few faults ... have been detected by detailed field mapping in the London area and south-east of Chelmsford, none has been proved in the [Southend, Essex] district by this method'. They continue: 'Geophysical surveys have, however, suggested the presence of localised zones of small faults which may be partly associated with present-day major valleys'. Although some faults can be detected and surveyed by geophysical methods, these methods also depend to a 
large extent on there being a sufficient contrast in composition across the fault-zone. Also, while the value of regional geophysical surveys in delineating tectonic structures is recognised (for example, Lee et al., 1993), detailed geophysical surveys are too timeconsuming or costly to deploy as part of a regional large-scale geological mapping programme.

\subsection{Standards of proof of faulting}

The interpretation of a displacement of strata across an unexposed area such as a valley, or between two boreholes, is inherently ambiguous: in the absence of other information, it could be due either to a fault displacement or to a flexure in the strata. It appears that some BGS field geologists have been trained to require a very high standard of proof for the existence of a fault, and so in parts of the UK, such as south-eastern England, many such displacements may have been interpreted as local flexures, albeit perhaps marking a fault-zone 'at depth'. For example, this is the case for the 'Lilley Bottom Structure' in the Hitchin district of Hertfordshire, as described by Hopson et al. (1996, pp. 115-116), which appears to be a surface expression of faults along the north-east margin of the Midlands Microcraton (Mortimore, 2011, fig. 74; Woods and Chacksfield, 2012, fig. 7). It seems that some BGS geologists have followed a principle of not drawing a fault where there was another reasonable explanation.

Indeed, commonly there are plausible alternative interpretations of a displacement across unexposed ground. In at least one instance where small faults have been shown to exist by seismic survey, doubt over their possible origin by valley bulge rather than tectonic movement remained (Lake et al., 1986, p.23). Although several extensive faults were inferred from borehole records to be present at depth in the Romford (Dines and Edmunds, 1925) and Chelmsford (Bristow, 1985, fig. 13) districts of Essex, for example, they were not shown on the corresponding geological maps, presumably in the absence of proof that they reached the surface. Some of the same faults were inferred to have controlled the extent of the Crag Group in northern Essex and southern Suffolk (Bristow, 1983) but abrupt changes in elevation of the basal Crag surface have also been interpreted as the infill of palaeovalleys or as tidal scour hollows (Mathers and Zalasiewicz, 1988).

Also, BGS geologists, particularly those working in southern England, typically were trained to record the majority of their mapped lines while physically present in the field, rather than 'in the office'. The value of this principle for general field survey practice is still recognised at BGS, but in some instances, as described in the next section, the presence of a fault may become apparent only when a sufficiently large area has been surveyed and can be viewed on a map at an appropriate scale. Evidence for such a fault may be difficult to see on the ground. It is now accepted that some lines on the geological map can justifiably be inferred by construction, rather than by field observation, perhaps using information from the subsurface or from geophysical surveys, or observed by remote sensing.

It is likely that where the arguably over-cautious approach of 'if in doubt, leave it out' has been practised in the past, it has tended to become self-perpetuating as surveys were carried 
forward. If the existing maps (perhaps produced by respected senior colleagues) showed no faults, then subsequent workers will have tended to adopt a 'safer' interpretation, which was more defensible in the face of caution — and which did not require revision of recently published maps.

\subsection{Some examples of under-representation of faults and its consequences}

The effects of some past BGS practice in mapping faults can be seen in the Chalk of the North Downs of Kent, east of the River Medway (Fig. 2), which was surveyed progressively from the Chatham district, in the late 1930s (Dines et al., 1954), to the Ramsgate district, where the survey was completed in 1962 (Shephard-Thorn, 1988). The resurvey was carried out at 1:10 560 scale and, later, at 1:10 000 scale by numerous different officers of the Geological Survey (including many of considerable surveying experience, whose work is still regarded with justifiable respect) working at different times. The corresponding published medium-scale maps (1:63 360 and, later, at 1: 50000 scale) show very few faults in the Chalk (and those mostly at large exposures in quarries or at the coast, as described in the Canterbury and Folkestone districts by Smart et al. (1966, p.13), for example) (Fig. 4a) and the complementary memoirs suggest that the Chalk is displaced only by small faults of minor significance, if any. The map of the Ramsgate and Dover districts, which were the last to be surveyed, is a notable exception. Even here, however, although a significant fracture zone related to basement faulting is known to lie within the Dour Valley and to extend offshore across the line of the Channel Tunnel, no appreciable vertical displacement on it could be found onshore and no fault was shown on the contemporary map, even though the possibility of post-Cretaceous strike-slip movement is recognised (Shephard-Thorn, 1988, p.31).

However, when the geological maps of the Chalk in this area were re-examined during the early 2000s on behalf of the Environment Agency and the local water companies, it became clear that there is extensive faulting in the Chalk of East Kent, including a complex fault-zone approximately aligned with the valley of the River Great Stour where it crosses the Chalk (Aldiss et al., 2004). For this work, many of the lines of faulting were largely interpreted from the existing large-scale geological maps (albeit transferred to modern base-maps with $5 \mathrm{~m}$ contour sets), by plotting systematic offsets of structure contours for key formation boundaries. Others became apparent only when new lines representing the Chalk formation boundaries were compiled. The offsets associated with these faults are most clearly apparent if a map of the whole area is considered. The largest such lateral offset at the base of the Palaeogene Thanet Formation, of 8 km, occurs across the valley of the River Great Stour (Fig. 4b). A regional view also shows how the outcrop patterns in the North Downs from the Great Stour eastwards contrast with those between the rivers Great Stour and Medway (Fig. 2) (Farrant and Aldiss, 2002). Such an overview is facilitated by the BGS digital geological map DiGMapGB50, which was compiled from the published medium-scale paper maps during the 1990s (Smith, 2010). The pattern of offsets is less easy to discern on any of the individual map sheets at 1:50 000 scale, especially as these show superficial deposits in addition to the bedrock outcrops. The difficulty is even greater if one is looking at the original large-scale maps, and during the field survey itself the offsets would be extremely cryptic. Indeed, given the prior decades of collective BGS experience on the North Downs, it 
seems possible that little or no faulting would be expected to be present in East Kent. Even if the presence of an individual fault was suspected during the field survey or subsequent compilation, the evidence may have then been considered too weak to justify revising the existing maps. It is sometimes said that geological mappers 'map to a model'; in other words, their map is an interpretation that reflects their understanding of the local geology. In this context, the ' model' is the current paradigm for the collective understanding of the local geology. To 'map to a different model' that recognises significant faulting in East Kent required a paradigm shift, albeit on a much less grand scale than this term usually implies.

The recognition of faulting in the Chalk Group of East Kent is essential to an understanding of the local hydrogeology, which is characterised by hitherto unexplained lateral changes in groundwater level, emergences and sinks. For example, the previously enigmatic perennial Well Chapel Spring, 5 km east of Canterbury [National Grid Reference 620100, 156400] (Fig. 4), was shown, for the first time, to be fault-controlled (Aldiss et al., 2004).

The recognition of extensive faulting in the Chalk of East Kent may also be significant to the scientific study of the Late Cretaceous successions. Mortimore (1993, 2011) and Mortimore and Pomerol (1997) argue that tectonic control of Chalk sedimentology and stratigraphy is widespread, as also shown by Woods and Chacksfield (2012). It is likely, therefore, that the Chalk of East Kent, which includes the classic sections near Dover (Robinson, 1986; Gale, 1989, 1995; Mortimore, 1997) differs somewhat from that found in other parts of southern England: it cannot be assumed to be representative of the Southern Chalk Province (Mortimore et al., 2001) as a whole. This may be illustrated by the existence of the Margate Chalk Member, a characteristic facies within the Newhaven Chalk Formation that, south of the Thames, is confined to East Kent (Hopson, 2005). The distribution of an analogous facies in Suffolk forms the Blakenham Chalk Member, which includes chalk of the same age as the Margate Chalk, and which is also suspected to be fault-controlled (Woods et al., 2007).

The presence of folds and faults that are not shown on current geological maps has been inferred in various parts of the London Basin (Wooldridge, 1921, 1923; Wooldridge, 1926; Wooldridge and Linton, 1955), around the Thames estuary (Devoy, 1979), in Essex (Boswell, 1915; Greensmith and Tucker, 1980; D'Olier, 1982; Bristow, 1985), and in East Anglia (Bristow, 1983; Hamblin et al., 1997) from analysis of Palaeogene, Pleistocene or Holocene sequences at the surface or in boreholes, terrestrial geodetic surveys, or tide gauge records. In some cases, this work post-dates the compilation of the corresponding geological map. More usually, however, although the inferred structures might have been noted by the geological surveyors, it appears to have been concluded that there was insufficient evidence to demonstrate that surface faulting has occurred (rather than localised folding, for example) or to constrain the position of the fault (or fold) sufficiently accurately to show on a 1:50 000 scale map, rather than on a regional sketch-map, for example, as in the Chelmsford district of Essex (Bristow, 1985, fig. 13).

Nevertheless, there is considerable evidence that faults are widespread in London and the surrounding area, as summarised by Ellison et al. (2004) and de Freitas (2009). Portions of fault-zones, including some reverse faults and thrusts, are commonly exposed in excavations 
for civil engineering works (De la Condamine, 1850, 1852; Barrow, 1906; Chandler et al., 1998) or by boreholes drilled for ground investigation. Borehole core might directly sample a fault-zone, but where it does not the presence of a fault in a borehole can still be inferred from the occurrence of structural repetition or omission of part of the local stratigraphy. The occurrence of faulting can also be inferred from the displacement of correlatable marker beds or other stratigraphic horizons between neighbouring boreholes (Kirkpatrick and McCann, 1984; Page, 1995, fig. 2; Lenham et al., 2006; Newman, 2009; Mortimore et al., 2011). Seismic reflection surveys carried out in the River Thames have also revealed the presence of faults, for example at the site of the Thames Barrier (Fookes and Martin, 1978; Horner, 1984; Muir Wood, 1990; Fookes, 2006) and for the Jubilee Line Extension project (D. Page, written communication, 2009). Commonly, however, such observations provide evidence only for the existence of a fault but not of its extent, azimuthal orientation or inclination. Even the detailed survey at the Thames Barrier site demonstrated the width and length of the fault-zone only within the river channel.

\section{Geological modelling of faults}

The use of borehole records (and seismic reflection survey records) in three-dimensional (3D) geological modelling can, however, demonstrate the azimuthal orientation of an observed or inferred fault-zone. This can be approached in two ways, depending on the modelling method employed. Unless stated otherwise, these remarks apply equally to dip-slip faults and to strike-slip faults.

Structural contours can be constructed from an array of points (defined by three cartesian coordinates: $\mathrm{x}, \mathrm{y}, \mathrm{z}$ ) that represent a geological surface of some kind, such as the base of a formation. Such points are commonly inferred from borehole intersections but might instead be taken from seismic survey profiles, mapped outcrop patterns or surface exposures. In the past (Boswell, 1915; Dines and Edmunds, 1925, fig.1, for example), such construction would have employed manual, 'pencil and paper' methods but many computer software packages are now available for this purpose. Contoured formation boundaries commonly display linear zones of deflection, where the amount or direction of dip of the modelled surface changes. In some cases, such deflections can be interpreted as faults, depending on their position relative to the data points.

The computer software package GSI3D (Kessler and Mathers, 2004; Kessler et al., 2009; Ford et al., 2010) takes a fundamentally different approach to the 3D modelling of geological surfaces, in which an intersecting network of 2D cross-sections is constructed by a geologist, linking data points based on borehole records or other sources (Figs. 5a and 5b). The same process could be carried out using pencil and paper, constrained by the level of complexity and the time available. When the cross-sections have been completed, then the software package calculates a series of surfaces (Fig. 5c) whose shape is controlled by strings of points (nodes) along the corresponding interpreted lines within the cross-sections. Many of the nodes will correspond to the data points, where these are regarded as consistent with the model. In a similar way to the interpretation of deflected contour sets as faults, then changes in the apparent dip of strata within a single cross-section (Fig. 5a) can be suspected to mark a 
fault. As noted, a displacement between two neighbouring boreholes - or other constraining data points - could be interpreted to be the consequence of either a fault or a fold, in the absence of other evidence. However, where the data points are closely spaced the presence of a fault is likely to be inferred in preference to postulating the occurrence of a tightly constrained monocline or other type of flexure.

Where a fault is suspected to occur in a GSI3D cross-section, then its possible lateral continuation can be investigated by inspection of nearby cross-sections. If offsets with a consistent direction and amount of displacement are found in adjacent cross-sections, then the presence of an inferred fault can be corroborated.

If it is assumed that the fault-zone is planar, relatively narrow, and vertical, then the pairs of constraining data points in each cross-section form a two-dimensional 'envelope of constraint' within which the surface trace of the fault must lie (Fig. 5d). However, any of these three assumptions could be false. If the fault-zone is curved, then it is less tightly constrained by the data, although in the absence of contrary evidence a fault-zone would usually be assumed to be essentially planar over short distances. However, its position is more tightly constrained if the fault is known to be broad (relative to the space between the data points), or if it is inclined. A dip-slip fault (either normal or reversed) will most probably be inclined, rather than being vertical. Where a fault offset is seen between two boreholes in a cross-section, then either of these two constraining boreholes might have passed through such a dipping fault. Even in the absence of an observed fault plane, some borehole evidence of stratigraphic repetition (indicating reverse faulting) or omission (indicating normal faulting) would then be expected. If there is no anomaly in the stratigraphic thicknesses found in the constraining boreholes, then a dipping fault might nevertheless intersect the borehole 'stick' either above the base of the youngest undivided bedrock unit or below the top of the oldest. Therefore an inclined fault can meet the rockhead towards one side, or even outside of, the envelope defined by the constraining boreholes (Figs. 5d and 5e).

Indeed, depending on the depth of the displaced layers within the constraining boreholes, relative to the distance between them, the three-dimensional inclined envelope of constraint can be narrower than the two-dimensional envelope that can be inferred for a vertical fault. This is illustrated diagrammatically in Figure 5e, which shows two borehole 'sticks' in the same stratigraphical sequence but with an inferred fault displacement between them. As the angle of dip of the inclined envelope of constraint decreases then so does its width. This example shows how the envelope of constraint for a fault dipping at $70^{\circ}$ is half the width of that for a vertical fault between the same two boreholes. The angle at which the inclined envelope closes to zero thickness places a lower limit on the possible angle of dip of the inferred fault, if it is planar (Fig. 5e). It follows that an inclined fault will be more closely constrained by the adjacent boreholes than will a vertical one.

Even so, it can be difficult to infer the dip direction of the fault (and so to determine its sense of movement as normal or reversed) or to demonstrate whether it is predominantly a dip-slip or strike-slip structure. 


\section{Evidence for faulting in London from 3D geological models}

The earliest regional 3D geological model of the London area that was based on a large dataset of borehole records is that produced by the BGS LOCUS Project during the late 1990s (Strange et al., 1998). An example of the surfaces generated for the LOCUS model (Fig. 6) clearly shows linear deflections that can be interpreted as faults, as noted by Ellison et al. (2004, p.81). This work was extended by the more detailed modelling for the BGS LithoFrame50 3D geological model of the London area (Ford et al., 2008; Ford et al., 2010), on which work continues at present. For example, 3D modelling in south London demonstrates that the linear outcrop of the basal London Clay, for example at Sutton, is very probably fault controlled. Structure contours on the base of the London Clay show sets of deflections and discordances that indicate the likely presence of a fault-zone separating the London Clay from older Palaeogene deposits (Figs. 7a, 7b). This model is largely based on borehole records such as those in the Hackbridge area, where the bedrock is largely obscured by river terrace deposits (Fig. 7c). Alternative interpretations, for example as a monocline, are possible but are constrained by the horizontal distance of only $100 \mathrm{~m}$ between one of the constraining boreholes and the edge of the London Clay outcrop nearby (Fig. 7d). If the London Clay is not faulted as shown in Figure 7e, the difference in level of $30 \mathrm{~m}$ between these occurrences implies an apparent dip of about $17^{\circ}$. In the absence of specific evidence for folding at this location, which might have been the preferred interpretation in the past, it is here suggested that the simplest explanation of this displacement is that it is the consequence of a normal fault, downthrown to the north (Fig. 7e).

Cross-sections derived from ground investigations for several major engineering projects in London have delineated fault-zones (Page, 1995, fig. 2; Lenham et al., 2006; Newman, 2009; Newman et al., 2010), including some previously unrecognised, such as the Plaistow graben (a significant fault-zone in east London) and its possible lateral extensions (Mortimore et al., 2011). More detailed patterns of faulting have been demonstrated in 3D geological models for parts of London (Ford et al., 2010), both for the Chalk (Royse, 2010; Royse et al., 2010) and the Palaeogene (Aldiss et al., 2012).

Numerous lines of evidence for the existence of faulting beneath London, and the consequent 'compartmentalisation' of the bedrock, were presented by de Freitas (2009). Although his conclusion is not disputed, and nor are most of his lines of argument, one cited analysis is potentially misleading. He points out that examination of natural drainage channels in the London area, including those of the 'lost rivers of London' (Barton, 1992), shows that many reaches are linear and conform to a pattern that resembles a network of faults. Although de Freitas (2009) found that fractal analysis of this pattern is consistent with the hypothesis that these linear drainage channels do mark faults, empirical evidence from geological mapping in a variety of other faulted terrain (for example, an active orogenic arc in Sumatra (Aldiss et al., 1983); Mesozoic and Proterozoic siliciclastic sedimentary rocks and Archaean granitoid gneisses of Botswana (Aldiss et al., 1989), variably folded and thrust Late Palaeozoic siliciclastic rocks in the Falkland Islands (Aldiss and Edwards, 1998), and Mesozoic to Cenozoic limestones, sandstones and mudstones of southern and eastern England (British Geological Survey, 2006)) suggests to this author that this is unlikely to be generally true. 
Indeed, the relationship between lines of faulting and lines of drainage, where it exists, can be quite subtle. For example, part of the course of the Fleet River, one of the 'lost rivers' in East London (Barton, 1992), follows a linear valley for about $1 \mathrm{~km}$ above its confluence with the River Thames. Three-dimensional geological modelling of the Farringdon area (Aldiss et al., 2012) shows that rather than following a single, weakened fault-zone, this section of the River Fleet coincides with a minor graben (Fig. 9).

In other areas of the UK (and elsewhere) where faults can be mapped from surface displacements of interbedded sequences of contrasting lithology (as in the Jurassic of the Grantham district, Fig. 8, for example), faults do not closely follow drainage lines. Indeed, where fault rocks become relatively indurated, fault-zones can form topographic ridges. Some relationship between lines of drainage and of fracturing is to be expected, and can be found in the Chalk, for example, where valleys commonly coincide with zones of relatively high groundwater transmissivity (Downing et al., 1993; Jones and Robins, 1999). However, it is also to be expected that not all fracture zones are marked by valleys, nor that all valleys follow fracture zones. Similarly, not all faults follow valleys, and not all valleys mark faults. The caution appropriate to lineament interpretation is also discussed by Drury (1993, p.97), for example.

Comparing the faults that are shown on the geological maps of London, including those of the Wimbledon - Woolwich tectonic axis, with the natural drainage lines shown on 1:25 000 scale Ordnance Survey topographic maps, it is found that only about 10 per cent of the length of the mapped faults follows a drainage channel.

The occurrence of linear drainage channels is therefore an unreliable guide to the existence and position of faults, although some deflections in drainage channels and lineaments in the topography that coincide with boundaries or deflections in the distribution of geological units may be treated as subjects for further investigation as possible faults.

\section{Evidence for Quaternary faulting in the London region}

In most parts of the UK, especially in areas of tectonic stability such as the London Platform, it is normally assumed that near-surface fault movement pre-dates the Quaternary.

Conventionally, on BGS geological maps no distinction is made between faults that displace only bedrock and those that also displace superficial deposits (Mawer, 2002). Musson (2007) points out that the generally small size of British earthquakes compared with their typical depth of origin suggests that there is a very small chance that any fault rupture would extend to the surface. He also notes that no surface rupture has ever been reported in any British earthquake in modern or historical times, and that when Stewart et al. (2001) reviewed the evidence for palaeoseismic surface rupture in Scotland they concluded that the evidence for such rupture advanced in other studies is unreliable.

Nevertheless, there is some evidence that near-surface faulting has occurred in the London area and in East Anglia during the Quaternary. The existence of faults that displace Quaternary deposits would have important considerations for construction and for the use of resources, for the reasons mentioned in the introduction to this paper. For example, many of 
the Quaternary deposits in the London region are of a granular nature but overlie the London Clay or other clay bedrock, and so are likely to host perched aquifers. Even small faults that displace river terrace deposits could create the circumstances for subterranean 'ponding' that could be significant for local hydrogeological conditions. Indeed, contemporary fault movement might be expected to generate seismic activity. However, although the PSI data suggest that differential crustal movement within the London area continues at the present time, seismic hazard in the London region is considered to be low (Musson and Sargeant, 2007).

\subsection{Faulting in the Farringdon area}

A detailed 3D geological model of the Farringdon area of east central London was created in GSI3D. A network of cross-sections was constructed through the Palaeogene sequence and the superficial deposits, using records from 136 boreholes in an area about $500 \mathrm{~m}$ by $800 \mathrm{~m}$ in surface extent (Aldiss et al., 2012). Examination of these cross-sections using the methods described in this paper (Fig. 7) led to the recognition of seven faults with an apparent vertical displacement of between $2 \mathrm{~m}$ and $12 \mathrm{~m}$, including those forming the graben aligned with the River Fleet (Fig. 9).

Most of the Farringdon area is underlain by the Hackney Gravel, part of the fourth river terrace deposit of the River Thames (Ellison et al., 2004), which is itself almost entirely covered by anthropogenic deposits. The geological model shows that the Hackney Gravel is here generally between about 2 and $4 \mathrm{~m}$ thick, and that it rests on an approximately level surface. To the west of the River Fleet, that surface is at about $13 \mathrm{~m}$ above Ordnance Datum (OD) (ranging from 12.2 to $13.5 \mathrm{~m}$, in general), but to the east, the surface is about $2 \mathrm{~m}$ lower at $11 \mathrm{~m}$ OD (ranging from 8 to $12.2 \mathrm{~m}$ ) (Fig. 9). It is possible that this height difference reflects deposition on an uneven surface, perhaps a consequence of differential erosion prior to sedimentation (as at Hackney Downs, $5 \mathrm{~km}$ to the north-east of Farringdon (Gibbard, 1994, fig. 28), or that the portion to the east is younger than that to the west, but the simplest explanation seems to be that there has been differential movement on the Saffron Hill Fault following the deposition of the Hackney Gravel about 250000 years ago. Indeed, the position of a markedly linear section of the River Fleet within a graben partly bounded by this fault, noted in Section 4, implies that differential subsidence has also taken place during the Holocene.

\subsection{Recent and current regional differential ground movements}

Evidence that significant differential crustal movement has occurred in the London area during the Holocene, and that it continues at the present, is provided by data from a type of satellite RADAR interferometry known as PSI. PSI is based on the analysis of synthetic aperture radar (SAR) reflections detected during successive passes of a survey satellite. The Differential Interferometric SAR (DInSAR) technique measures differences in phase between interferograms generated from succeeding SAR images. These phase differences correspond to changes in the distance between the satellite and the ground, and by knowing the precise position of the satellite, they can in turn be related to movements of the ground surface over 
time. PSI is a DInSAR technique that considers the phase differences in a series of SAR images for a specific area and selects pixels based on their phase stability through time: these pixels are referred to as 'Persistent Scatterer' (PS) points (Ferretti et al., 1999). PS points correspond to stable, radar-reflective objects such as built structures or bare rock (Riedmann and Haynes, 2007).

A study of present-day ground motion in the London and Thames estuary area was carried out in an area approximately $95 \times 55 \mathrm{~km}$ in extent, centred just east of London. A total of 82 descending ERS and ENVISAT SAR scenes (Track 51, Frame 2565) spanning nearly nine years (March 1997 to December 2005) were processed by Nigel Press Associates Ltd., generating a dataset of about 950000 PS points (Bingley et al., 2007; Bingley et al., 2008).

A scatter plot of these data revealed, amongst other things, a north-east to south-west oriented lineament separating a region of north-west London where the ground is generally subsiding at $0.5 \mathrm{~mm} /$ year or less, from a region to the south-east where the ground is generally subsiding at $1.0 \mathrm{~mm} /$ year or more (Bingley et al., 2008; Aldiss et al., in prep). These rates of movement are comparable with those determined for the Thames estuary area by analysis of Quaternary deposits of known age and relationship to sea level (Shennan et al., 2006; Gehrels, 2010). The north-east-south-west lineament is approximately coincident with inferred north-east-south-west faults within the pre-Mesozoic basement that are thought to form the south-eastern margin of the Midlands Microcraton (Aldiss et al., in prep.). It partly coincides with a portion of the north-east-south-west Wimbledon Fault and it lies close to the Plaistow graben (Mortimore et al., 2011) (Fig. 10). The lineament crosses the River Thames just to the east of the Tower of London, where the width of the flood plain abruptly increases from about $1 \mathrm{~km}$ to about $3 \mathrm{~km}$, so that downstream the alluvium covers the Kempton Park Gravel (which forms the second river terrace deposit of the River Thames). To the east, the Kempton Park Gravel is, like the Shepperton Gravel of the first terrace, almost entirely suballuvial (Fig. 10). This abrupt change in the configuration of the alluvial deposits suggests that near-surface tectonic movement has occurred on this lineament during the Holocene. However, the lineament could correspond to a zone as much as $500 \mathrm{~m}$ wide, consistent with a movement on a basement fault that has propagated towards the surface. Although its alignment with some known fault-zones suggests that it could mark other fault displacements at fairly shallow depths, it does not demonstrate that fault ruptures extend into the Quaternary deposits.

The PSI land level change data also suggest a differential vertical ground motion of about $0.6 \mathrm{~mm} /$ year across a lineament passing through the Medway valley in the North Downs in Kent (Fig. 10; Aldiss et al., in prep). Plentiful evidence of faulting in the Chalk just east of the Medway was found during construction of the North Downs railway tunnel (Warren and Mortimore, 2003). As with the lineament to the west in central London, although this current differential motion might be accommodated by some fault displacement at depth, it does not demonstrate that Holocene displacement extends to the surface.

The north-east - south-west lineaments, and linear structures, in London and in the Medway valley lie parallel to a series of major lineaments visible in the regional Bouguer gravity field 
and, in some instances, in the surface topography (Fig. 11). It is unlikely that these lineaments correspond exactly to near-surface faults, but they are thought to reflect the presence of fault-zones at some level, such as the Witham and Wickham Bishops faults in the Chelmsford district (Bristow, 1985, fig. 13). It is likely that such fault-zones would be longlived and they could vary in complexity with depth. The Palaeogene London Basin (Fig. 2) is elongated parallel to these lineaments, consistent with its origin as a south-westerly arm of the southern North Sea Basin (Aldiss, 2012). The lineaments may mark fault-zones that controlled the formation of the London Basin.

Faults associated with these lineaments, where they exist, would be expected to have mainly south-easterly dip-slip downthrows or sinistral strike-slip movements, or elements of both (compare de Freitas, 2009, fig. 16). The inferred epicentre of the 1884 Colchester earthquake lies close to one of these lineaments, which is approximately parallel to the reverse Wickham Bishops Fault (Bristow, 1985), and some 4 to $6 \mathrm{~km}$ south-east of it. This earthquake is believed to have originated at a relatively shallow level of about $3 \mathrm{~km}$ (Musson, 2007), which is consistent with an origin on a fault-zone that dips south-eastwards at between about $60^{\circ}$ and $70^{\circ}$ and that crops out on the nearby lineament.

\subsection{Archaeological evidence for palaeoseismicity}

Perhaps the least equivocal evidence for Quaternary faulting in the London area was found in an archaeological excavation in the Beckton area of east London. The excavation discovered a landscape surface at -1.72 m Ordnance Datum, dating to about 3500 years BP, buried beneath peat, alluvial clay and made ground. The surface included a trackway constructed of coppiced alder, of a type then used to facilitate crossing the marshy ground of the Thames flood plain. At one point, the trackway was found to be sharply broken and offset by $0.1 \mathrm{~m}$ laterally and $0.13 \mathrm{~m}$ vertically, with the space filled by clay. This offset is attributed to fault displacement sometime after the cessation of peat formation at about 2900 years BP, but before the deposition of the made ground (Meddens and Sidell, 1995). The underlying Holocene deposits are less than about $3 \mathrm{~m}$ thick, and rest on between 1 and $4.1 \mathrm{~m}$ of river terrace deposits overlying London Clay bedrock, so that differential compaction within the Quaternary deposits seems to offer a less likely alternative mechanism for this offset.

\subsection{Quaternary faulting in East Anglia}

Balson and Humphreys (1986) describe evidence for the formation of tectonic fissures and, in one place, a small fault during the early Pleistocene in east Suffolk, while Hamblin et al. (1997) demonstrate more extensive displacements of these deposits. Hopson and Bridge (1987) point out a vertical displacement of between 5 and $10 \mathrm{~m}$ within the mid-Pleistocene Corson Formation, in south Norfolk, but could not demonstrate conclusively that it reflects near-surface faulting.

\section{Conclusions}

The absence of a fault on a geological map does not demonstrate that no faulting is present: it may just reflect a lack of information. Faults in general appear to have been widely under- 
represented on BGS geological maps in the London area and elsewhere, especially in the south and east of England. This situation has probably arisen through a combination of factors including a general expectation that few significant faults are present at the surface in these areas, a requirement by some geologists for a very high standard of proof of the existence of a fault and a requirement that the position of mapped structures be known accurately at large and medium map scales. Some geological maps show only structures that could be inferred during large-scale field survey.

However, faulting is widespread in the bedrock under the London area. Differential crustal movements, partly controlled by deep-seated faults, continue at the present day, although this is not necessarily accompanied by displacement on fault-zones close to the surface. However, there is some evidence, although none that is entirely conclusive, that near-surface fault displacement in the London area has occurred during the Quaternary, including the Holocene.

If these conclusions are true for one of the least tectonically active parts of the UK, as shown by the sedimentary record and the distribution of recorded earthquakes, then they are likely also to be true for many other parts of the UK. It seems probable that if fault displacement of Quaternary deposits occurs, it may be overlooked for lack of evidence, or possibly because it is simply not expected.

By itself, field survey is commonly insufficient to recognise and delineate faults in poorly exposed ground unless there is a distinct lithological contrast and little superficial or anthropogenic cover. This paper shows the potential value of combining different kinds of information and of modelling techniques that allow new interpretations of the geological structure of an area to be determined. In particular, it is necessary to appraise broad areas as well as local detail. While field observation remains the most useful single tool of the geological surveyor, useful insights can be gained from other datasets, especially where these are used in combination.

If it is accepted that geological maps may show structures whose position is not known exactly at the largest scale of mapping, and that the occurrence of faults can be inferred from a variety of datasets now available to the geologist, including those derived from geophysical surveys, from satellite or airborne observation and from borehole records, and by geological modelling techniques of various kinds, then it is possible to recognise and delineate more faults, and with more confidence, than was previously possible by using large-scale field survey alone.

\section{Acknowledgements}

This paper is based on a presentation to a meeting of the London Basin Forum at the Geological Society of London at Burlington House, on 28 October 2009. I am grateful to Jackie Skipper, particularly for telling me about the ruptured trackway at Becton, Alan Smallwood for encouraging me to publish, and to Darren Page for his support and help, especially with literature research. I thank my BGS colleagues for discussion of relevant 
topics over many years, especially Barrie Chacksfield for recognising extra lineaments in the regional gravity data and their links to topography, as well as for processing that data, Richard Ellison, Steve Mathers, John Powell and Jon Ford for helpful comments on early drafts of this paper, Peter Hopson for debates of chalk mapping methods, Roger Musson for information about earthquakes, and Kate Royse who first drew my attention to the fault-zone in south London (Fig. 9), noted during her work on a model of the Chalk under London.

Steve Mathers and Helen Burke produced the relevant part of the London LithoFrame50 3D geological model. Support by the Environment Agency, Southern Water, Mid Kent Water and Veolia for the revision of the geological maps of East Kent is gratefully acknowledged. However, I take responsibility for the interpretations presented in this paper.

I thank the two anonymous referees for their challenging and helpful comments.

This paper is published with the permission of the Executive Director, BGS (NERC).

\section{References}

Aldiss, D.T., 2012. The stratigraphical framework for the Palaeogene successions of the London Basin, UK. British Geological Survey Open Report OR/12/004. Available from http://nora.nerc.ac.uk/17121/.

Aldiss, D.T., Whandoyo, R., Ghazali, S.A., Kusyono, 1983. The geology of the Sidikalang Quadrangle, northern Sumatra (with 1:250 000 geological map, sheets NA 47-5, 47-6). Geological Research and Development Centre, Bandung, Indonesia (Bandung).

Aldiss, D.T., Tombale, A.R., Mapeo, R.M.B., Chiepe, M., 1989. The geology of the Kanye area. Bulletin of the Geological Survey of Botswana 33, 172 pp.

Aldiss, D.T., Edwards, E.J., 1998. Geology of the Falkland Islands. Solid geology. 1:250 000, [2 folded maps + leaflet]. Falkland Islands Government, Stanley, Falklands.

Aldiss, D.T., Black, M.G., Entwisle, D.C., Page, D.P., Terrington, R.L., 2012. Benefits of a 3D geological model for major tunnelling works: an example from Farringdon, east-central London, UK. Quarterly Journal of Engineering Geology and Hydrogeology 45, 405-414.

Aldiss, D.T., Bloomfield, J.R., Buckley, D.K., Doran, S.K., Evans, D.J., Hopson, P.M., Royse, K.R., Woods, M.A., 2004. A geological model of the Chalk of East Kent. British Geological Survey Commissioned Report, CR/04/092.

Aldiss, D.T., Burke, H.C., Chacksfield, B.C., Bingley, R.M., Teferle, F.N., Williams, S.D.P., Blackman, D.L., Reidmann, M., Press, N., in prep. Geological interpretation of current subsidence and uplift in the London and Thames estuary area, UK, as shown by highprecision satellite-based surveying.

Balson, P.S., Humphreys, B., 1986. The nature and origin of fissures in the East Anglian Coralline and Red Crags. Journal of Quaternary Science 1, 13-19.

Barrow, G., 1906. Notes on recent excavations in the London area, Summary of Progress of the Geological Survey of the United Kingdom and Museum of Practical Geology for 1905. Memoir of the Geological Survey of Great Britain pp. 167-169. 
Barton, N., 1992. The lost rivers of London, 2nd ed., Historical Publications Ltd, London.

Bingley, R., Teferle, F.N., Orliac, E.J., Dodson, A.H., Williams, S.D.P., Blackman, D.L., Baker, T.F., Riedmann, M., Haynes, M., Aldiss, D.T., Burke, H.C., Chacksfield, B.C., Tragheim, D.G., 2007. Absolute fixing of tide gauge benchmarks and land levels: Measuring changes in land and sea Levels around the coast of Great Britain and along the Thames estuary and River Thames using GPS, absolute gravimetry, Persistent Scatterer Interferometry and tide gauges. Defra (Department for Environment, Food and Rural Affairs) R\&D Technical Report, FD2319/TR. Available from http://sciencesearch.defra.gov.uk/Document.aspx?Document=FD2319_5408_TRP.pdf.

Bingley, R.M., Teferle, F.N., Orliac, E.J., Dodson, A.H., Williams, S.D.P., Blackman, D.L., Baker, T.F., Riedmann, M., Haynes, M., Press, N., Aldiss, D.T., Burke, H.C., Chacksfield, B.C., Tragheim, D., Tarrant, O., Tanner, S., Reeder, T., Lavery, S., Meadowcroft, I., Surendran, S., Goudie, J.R., Richardson, D., 2008. Measurement of current changes in land levels as input to long-term planning for flood risk management along the Thames estuary. Journal of Flood Risk Management 1, 162-172.

Boswell, P.G.H., 1915. The stratigraphy and petrology of the Lower Eocene deposits of the north-eastern part of the London Basin. Quarterly Journal of the Geological Society 71, 536591.

Brenchley, P.J., Rawson, P.F., 2006. The geology of England and Wales. The Geological Society, London.

Bristow, C.R., 1983. The stratigraphy and structure of the Crag of mid-Suffolk, England. Proceedings of the Geologists' Association 94, 1-12.

Bristow, C.R., 1985. Geology of the country around Chelmsford. Memoir of the British Geological Survey Sheet 241 (England and Wales).

British Geological Survey. 2006. Newbury. England and Wales Sheet 267. Solid and Drift Geology. 1:50 000. (Keyworth, Nottingham: British Geological Survey.)

Busby, J.P., Smith, N.J.P., 2001. The nature of the Variscan basement in southeast England: evidence from integrated potential field modelling. Geological Magazine 138, 669-685.

Chadwick, R.A., 1993. Aspects of basin inversion in Southern Britain. Journal of the Geological Society, London 150, 893-911.

Chadwick, R.A., Evans, D.J., 2005. A seismic atlas of southern Britain -- images of subsurface structure. Occasional Publication No. 7, British Geological Survey, Keyworth, Nottingham.

Chandler, R.J., Willis, M.R., Hamilton, P.S., Andreou, I., 1998. Tectonic shear zones in the London Clay Formation. Geotechnique 48, 257-270.

D'Olier, B., 1982. Differential subsidence on the Essex coast. Proceedings of the Geologists' Association 93, 317-318.

de Freitas, M.H., 2009. Geology; its principles, practice and potential for Geotechnics. Quarterly Journal of Engineering Geology and Hydrogeology 42, 397-441. 
De la Condamine, H.M., 1850. On the Tertiary strata and their dislocations in the neighbourhood of Blackheath. Quarterly Journal of the Geological Society 6, 440-449.

De la Condamine, H.M., 1852. On a reversed fault at Lewisham. Quarterly Journal of the Geological Society 8, 193-195.

Devoy, R.J.N., 1979. Flandrian sea level changes and vegetation history of the Lower Thames estuary. Philosophical Transactions of the Royal Society of London B285, 355-407.

Dines, H.G., Edmunds, F.H., 1925. The geology of the country around Romford. Memoir of the Geological Survey of Great Britain Sheet 257 (England and Wales).

Dines, H.G., Holmes, S.C.A., Robbie, J.A., 1954. Geology of the country around Chatham. Memoir of the Geological Survey Sheet 272 (England and Wales).

Downing, R.A., Price, M., Jones, G.P., 1993. The making of an aquifer, In: Downing, R.A., Price, M., Jones, G.P. (Eds.), The Hydrogeology of the Chalk of North-West Europe. Clarendon, Oxford, pp. 1-13.

Drury, S.A., 1993. Image interpretation in geology, 2nd ed. Chapman \& Hall London.

Ellison, R.A., Woods, M.A., Allen, D.J., Forster, A., Pharaoh, T.C., King, C., 2004. Geology of London. Memoir of the British Geological Survey Sheets 256 (North London), 257 (Romford), 270 (South London) and 271 (Dartford) (England and Wales).

Farrant, A.R., Aldiss, D.T., 2002. A geological model of the North Downs of Kent: The River Medway to the River Great Stour. British Geological Survey Commissioned Report, $\mathrm{CR} / 02 / 310$.

Ferretti, A., Rocca, F., Prati, C., 1999. Non-uniform motion monitoring using the permanent scatterers technique, FRINGE '99: Second ESA International Workshop on ERS SAR Interferometry, Liège, ESA, pp. 1-6.

Fookes, P.G., 2006. Thames Barrier 21st anniversary in News and Comment. Geology Today 22, 48-50.

Fookes, P.G., Martin, P.L., 1978. Site investigation and geotechnical considerations, Thames Barrier Design. ICE Publishing, London, pp. 29-50.

Ford, J.R., Burke, H.F., Royse, K.R., Mathers, S.J., 2008. The 3D geology of London and the Thames Gateway: a modern approach to geological surveying and its relevance in the urban environment, Cities and their underground environment : 11th European e-conference of International Association for Engineering Geology, Madrid, Spain, pp. 15-19.

Ford, J.R., Mathers, S.J., Royse, K.R., Aldiss, D.T., Morgan, D.J.R., 2010. Geological 3D modelling: scientific discovery and enhanced understanding of the subsurface, with examples from the UK. Zeitschrift der Deutschen Gesellschaft für Geowissenschaften 161, 205-218.

Gale, A.S., 1989. Field meeting at Folkestone Warren, 29th November 1987. Proceedings of the Geologists' Association 100, 73-80. 
Gale, A.S., 1995. Cyclostratigraphy and correlation of the Cenomanian stage in western Europe, In: House, M.R., Gale, A.S. (Eds.), Orbital forcing timescales and cyclostratigraphy. Geological Society of London Special Publication 85, pp. 177-197.

Gehrels, W.R., 2010. Late Holocene land- and sea-level changes in the British Isles: implications for future sea-level predictions. Quaternary Science Reviews 29, 1648-1660.

Gibbard, P.L., 1994. Pleistocene history of the Lower Thames valley. Cambridge University Press.

Gillespie, M.R., Barnes, R.P., Milodowski, A.E., 2011. British Geological Survey scheme for classifying discontinuities and fillings. British Geological Survey Research Report, RR/10/05 (Keyworth, Nottingham). Available from http://nora.nerc.ac.uk/13986/.

Greensmith, J.T., Tucker, E.V., 1980. Evidence for differential subsidence on the Essex coast. Proceedings of the Geologists' Association 91, 169-175.

Hamblin, R.J.O., Moorlock, B.S.P., Booth, S.J., Jeffery, D.H., Morigi, A.N., 1997. The Red Crag and Norwich Crag formations in eastern Suffolk. Proceedings of the Geologists' Association 108, 11-23.

Hopson, P.M., 2005. A stratigraphical framework for the Upper Cretaceous Chalk of England and Scotland with statements on the Chalk of Northern Ireland and the UK Offshore Sector. British Geological Survey Research Report, RR/05/01 (Nottingham). Available from http://nora.nerc.ac.uk/3230/.

Hopson, P.M., Aldiss, D.T., Smith, A., 1996. The geology of the country around Hitchin. Memoir of the British Geological Survey Sheet 221 (England and Wales).

Hopson, P.M., Bridge, D.M., 1987. Middle Pleistocene stratigraphy in the lower Waveney valley, East Anglia. Proceedings of the Geologists' Association 98, 171-185.

Horner, R.W., 1984. The Thames tidal flood risk-the need for the barrier: a review of its design and construction. Quarterly Journal of Engineering Geology and Hydrogeology 17, 199-206.

Jones, H.K., Robins, N.S., 1999. The Chalk aquifer of the South Downs. Hydrogeological Report Series of the British Geological Survey.

Kessler, H., Mathers, S., Sobisch, H.-G., 2009. The capture and dissemination of integrated 3D geospatial knowledge at the British Geological Survey using GSI3D software and methodology. Computers \& Geosciences 35, 1311-1321.

Kessler, H., Mathers, S.J., 2004. Maps to models. Geoscientist 14, 4-6.

King, C., 2006. Paleogene and Neogene: uplift and a cooling climate, In: Brenchley, P.J., Rawson, P.F. (Eds.), The geology of England and Wales. The Geological Society, London, pp. 395-427. 
Kirkpatrick, I.M., McCann, D.M., 1984. Engineering geological and geophysical investigation of the Barking Creek tidal barrier site. Quarterly Journal of Engineering Geology and Hydrogeology 17, 259-268.

Knox, R.W.O., 1996. Tectonic controls on sequence development in the Palaeocene and earliest Eocene of southeast England: implications for North Sea stratigraphy, In: Hesselbro, S.P., Parkinson, D.N. (Eds.), Sequence Stratigraphy in British Geology. Geological Society of London Special Publication 103, pp. 209-230.

Lake, R.D., Ellison, R.A., Henson, M.R., Conway, B.W., 1986. Geology of the country around Southend and Foulness. Memoir of the British Geological Survey Sheet 258 and 259 (England and Wales).

Lake, R.D., Young, B., Wood, C.J., Mortimore, R.N., 1987. Geology of the country around Lewes. Memoir of the British Geological Survey Sheet 319 (England and Wales).

Lee, M.K., Pharaoh, T.C., Williamson, J.P., Green, C.A., De Vos, W., 1993. Evidence on the deep structure of the Anglo-Brabant Massif from gravity and magnetic data. Geological Magazine 130, 575-582.

Lenham, J., Meyer, V., Edmonds, H., Harris, D., Mortimore, R.N., Reynolds, J., Black, M., 2006. What lies beneath: surveying the Thames at Woolwich. Proceedings of the Institute of Civil Engineering - Civil Engineering 159, 32-41.

Mathers, S.J., Zalasiewicz, J.A., 1988. The Red Crag and the Norwich Crag formations of southern East Anglia. Proceedings of the Geologists' Association 99, 261-278.

Mawer, C.H., 2002. Cartographic standard geological symbol index. Version 3. British Geological Survey Research Report, RR/01/01 (Keyworth, Nottingham). Available from http://nora.nerc.ac.uk/3221/.

McMillan, A.A., Hamblin, R.J.O., Merritt, J.W., 2011. A lithostratigraphical framework for onshore Quaternary and Neogene (Tertiary) superficial deposits of Great Britain and the Isle of Man. British Geological Survey Research Report, RR/10/03. Available from http://nora.nerc.ac.uk/14531/.

Meddens, F.M., Sidell, J., 1995. Bronze age trackways in east London. Current Archaeology 12, 412-416.

Mortimore, R.N., 1993. Chalk, water and engineering geology, In: Downing, R.A., Price, M., Jones, G.P. (Eds.), The hydrogeology of the Chalk of north-west Europe. Oxford Science Publications. Clarendon Press, Oxford, pp. 67-92.

Mortimore, R.N., 1997. The Chalk of Sussex and Kent. Geologists' Association Guide, 57.

Mortimore, R.N., 2011. A chalk revolution: what have we done to the Chalk of England? Proceedings of the Geologists' Association 122, 232-297.

Mortimore, R.N., Newman, T.G., Royse, K., Scholes, H., Lawrence, U., 2011. Chalk: its stratigraphy, structure and engineering geology in east London and the Thames Gateway. Quarterly Journal of Engineering Geology and Hydrogeology 44, 419-444. 
Mortimore, R.N., Pomerol, B., 1997. Upper Cretaceous tectonic phases and end Cretaceous inversion in the chalk of the Anglo-Paris basin. Proceedings of the Geologists' Association 108, 231-255.

Mortimore, R.N., Wood, C.J., Gallois, R.W., 2001. British Upper Cretaceous Stratigraphy. Geological Conservation Review Series, 23, Joint Nature Conservation Committee, Peterborough.

Muir Wood, R., 1990. London: not waving but drowning. Terra Nova 2, 284-291.

Musson, R.M.W., 2007. British earthquakes. Proceedings of the Geologists' Association 118, 305-337.

Musson, R.M.W., Sargeant, S.L., 2007. Eurocode 8 seismic hazard zoning maps for the UK. British Geological Survey Technical Report, CR/07/125 (Nottingham).

Newman, T., 2009. The impact of adverse geological conditions on the design and construction of the Thames Water Ring Main in Greater London, UK. Quarterly Journal of Engineering Geology and Hydrogeology 42, 5-20.

Newman, T.G., Yuan, L.F.V., O'Keeffe, L.C., 2010. Using tunnel boring data to augment the geological model. Geotechnical Engineering 163, 157-166.

Owen, H.G., 1971. The stratigraphy of the Gault in the Thames estuary and its bearing on the Mesozoic tectonic history of the area. Proceedings of the Geologists' Association 82, 187207.

Page, D.P., 1995. Jubilee Line Extension. Quarterly Journal of Engineering Geology 28, 97104.

Pharaoh, T.C., Molyneux, S.G., Merriman, R.J., Lee, M.K., Verniers, J., 1993. The Caledonides of the Anglo-Brabant massif reviewed. Geological Magazine 130, 561-562.

Rawson, P.F., 2006. Cretaceous: sea levels peak as the North Atlantic opens, In: Brenchley, P.J., Rawson, P.F. (Eds.), The geology of England and Wales. The Geological Society, London, pp. 365-393.

Riedmann, M., Haynes, M., 2007. Developments in synthetic aperture radar interferometry for monitoring geohazards, In: Teeuw, R.M. (Ed.), Mapping hazardous terrain using remote sensing. Special Publication Geological Society, London 283, pp. 45-51.

Robinson, N.D., 1986. Lithostratigraphy of the Chalk Group of the North Downs, southeast England. Proceedings of the Geologists’ Association 97, 141-170.

Royse, K.R., 2010. Combining numerical and cognitive 3D modelling approaches in order to determine the structure of the Chalk in the London Basin. Computers \& Geosciences 36, 500511.

Royse, K.R., Kessler, H., Robins, N.S., Hughes, A.G., Mathers, S.J., 2010. The use of 3D geological models in the development of the conceptual groundwater model. Zeitschrift der Deutschen Gesellschaft für Geowissenschaften 161, 237-249. 
Shennan, I., Bradley, S., Milne, G., Brooks, A., Bassett, S., Hamilton, S., 2006. Relative sealevel changes, glacial isostatic modelling and ice-sheet reconstructions from the British Isles since the Last Glacial Maximum. Journal of Quaternary Science 21, 585-599.

Shephard-Thorn, E.R., 1988. Geology of the country around Ramsgate and Dover. Memoir of the British Geological Survey Sheets 274 and 290 (England and Wales).

Smart, J.G.O., Bisson, G., Worssam, B.C., 1966. Geology of the country around Canterbury and Folkestone. Memoir of the Geological Survey of Great Britain Sheets 289, 305 and 306 (England and Wales).

Smith, A., 2010. Digital geological map of Great Britain, information notes 2011. British Geological Survey Open Report, OR/10/050. Available from http://nora.nerc.ac.uk/19839/.

Stewart, I.S., Firth, C., Rust, D.J., Collins, P.E.F., Firth, J.A., 2001. Postglacial fault movement and palaeoseismicity in western Scotland: A reappraisal of the Kinloch Hourn fault, Kintail. Journal of Seismology 5, 307-328.

Strange, P.J., Booth, S.J., Ellison, R.A., 1998. Development of 'rockhead' computer-generated geological models to assist geohazard prediction in London, In: Maund, J.G., Eddleston, M. (Eds.), Geohazards in Engineering Geology. Geological Society, London, Engineering Geology Special Publications 15, pp. 409-414.

Sumbler, M.G., 1996. British regional geology: London and the Thames Valley, Fourth ed., HMSO for the British Geological Survey, London.

Warren, C.D., Mortimore, R.N., 2003. Chalk engineering geology - Channel Tunnel Rail Link and North Downs Tunnel. Quarterly Journal of Engineering Geology and Hydrogeology 36, 17-34.

Woods, M.A., Chacksfield, B.C., 2012. Revealing deep structural influences on the Upper Cretaceous Chalk of East Anglia (UK) through inter-regional geophysical log correlations. Proceedings of the Geologists' Association 123, 486-499.

Woods, M.A., Wood, C.J., Wilkinson, I.P., Wright, T.N., 2007. The stratigraphy of the Chalk Group (Upper Cretaceous) of the Gipping Valley, near Ipswich, Suffolk, UK. Proceedings of the Geologists Association 118, 347-363.

Wooldridge, S.W., 1921. Evidence for folding in the Tertiary and Cretaceous rocks near South Mimms and Ridge Hill: With Report of Excursion, May 28th, 1920. Proceedings of the Geologists' Association 32, 227-231.

Wooldridge, S.W., 1923. The minor structures of the London Basin. Proceedings of the Geologists' Association 34, 175-193, IN171.

Wooldridge, S.W., 1926. The structural evolution of the London Basin. Proceedings of the Geologists' Association 37, 162-196.

Wooldridge, S.W., Linton, D.L., 1955. Structure, surface and drainage in south-east England. George Philip and Son, London. 
Figures with captions to accompany

\section{Under-recording of faults on geological maps of the London region: reasons, consequences and solutions}

D T Aldiss

Figures in colour are intended for colour reproduction on the Web and in print

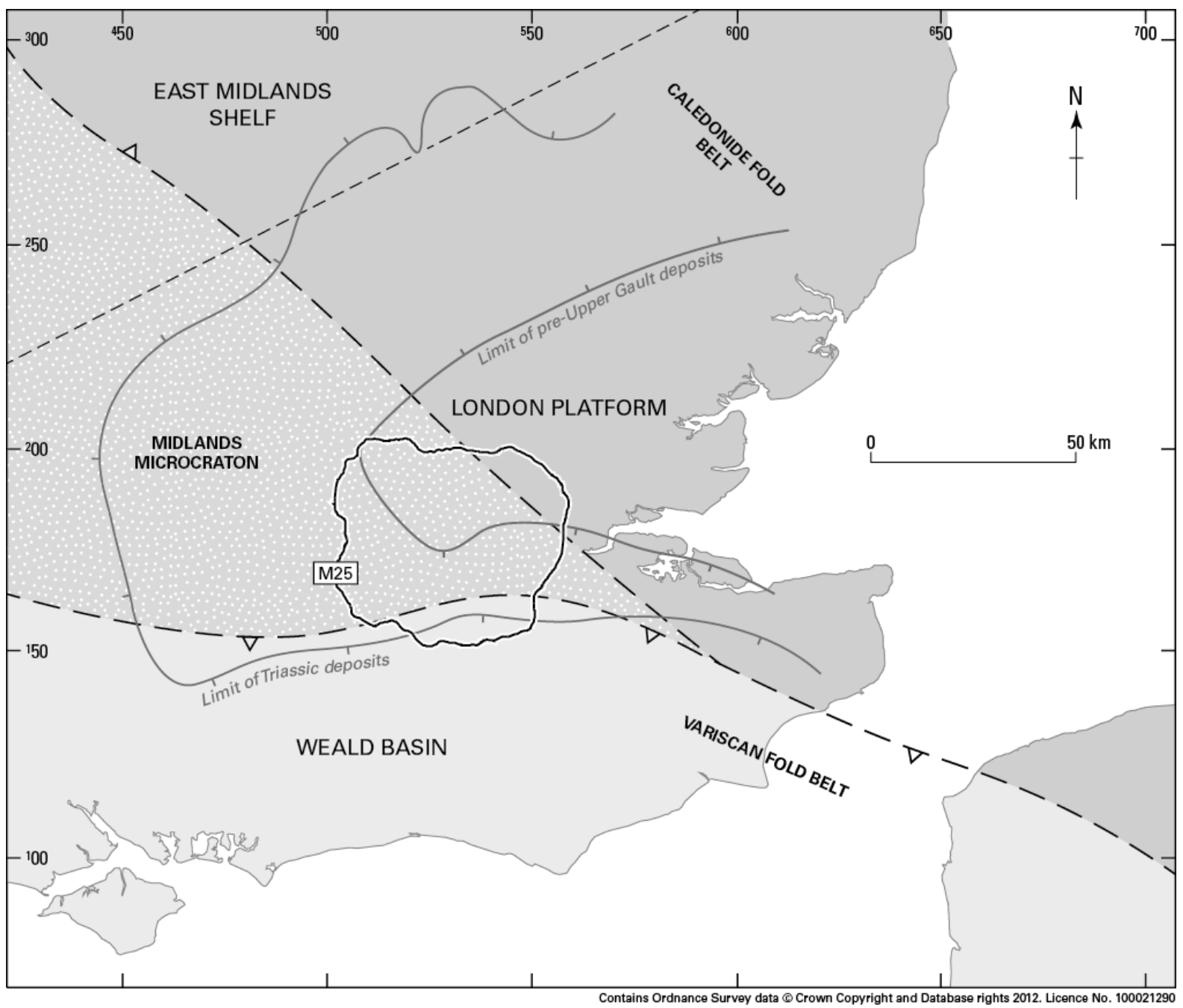

Fig. 1. Summary of tectonic units in south-eastern England

Basement terrains named in smaller, bold type. Post-Caledonian depositional areas named in larger, regular type.

Extent of Triassic and pre-Upper Gault Cretaceous formations after Sumbler (1996). Position of London indicated by M25 orbital motorway. 


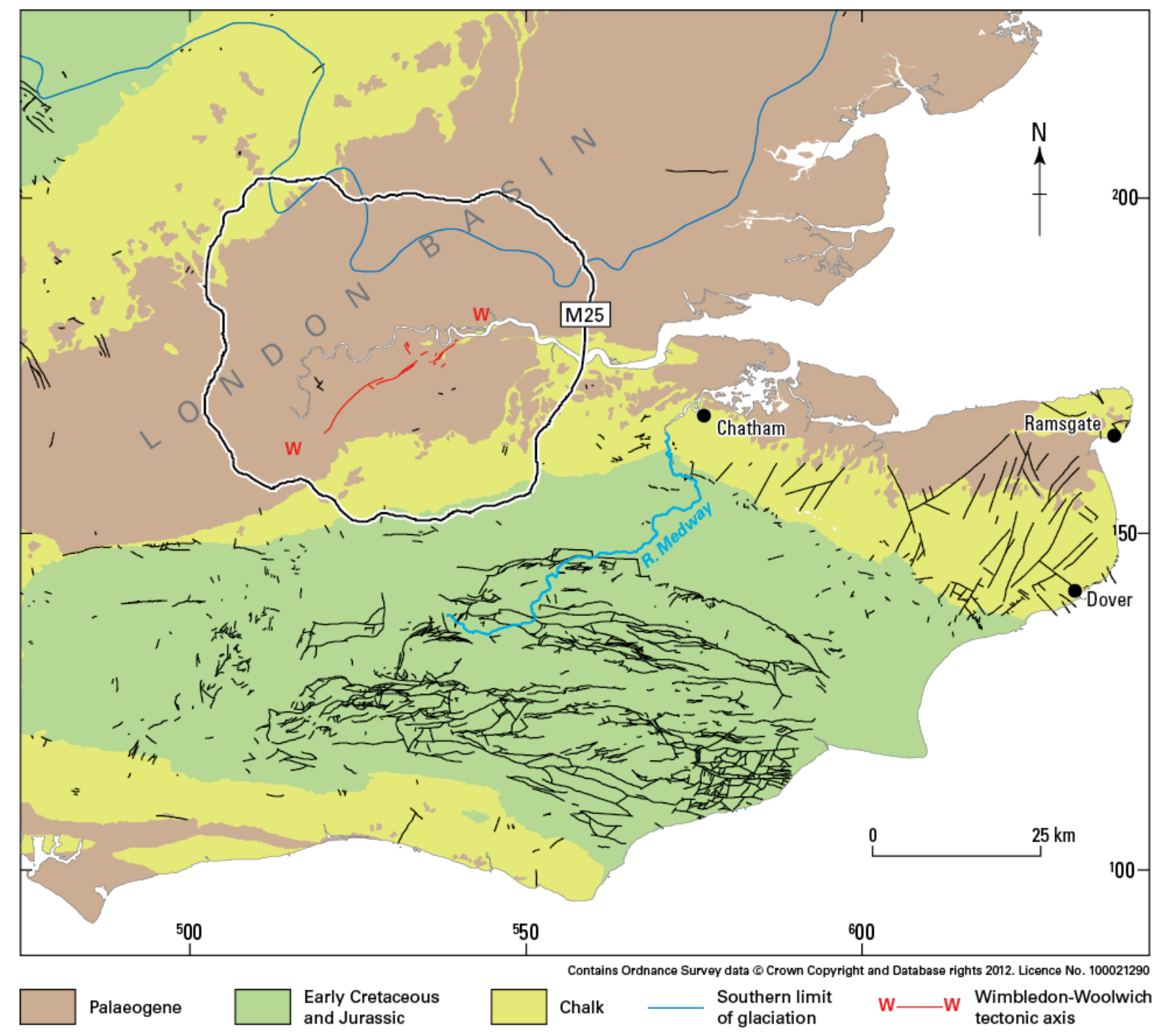

Fig. 2. Mapped faults in south-eastern England

Bedrock geology from DiGMapGB-625

(http://www.bgs.ac.uk/products/digitalmaps/digmapgb_625.html).

Faults taken from DiGMapGB-50 (http://www.bgs.ac.uk/data/services/digmap50wms.html).

Anglian glacial limit from McMillan et al. (2011). Position of London indicated by M25 orbital motorway. Extent of London Platform is indicated in Figures 1 and 3. 


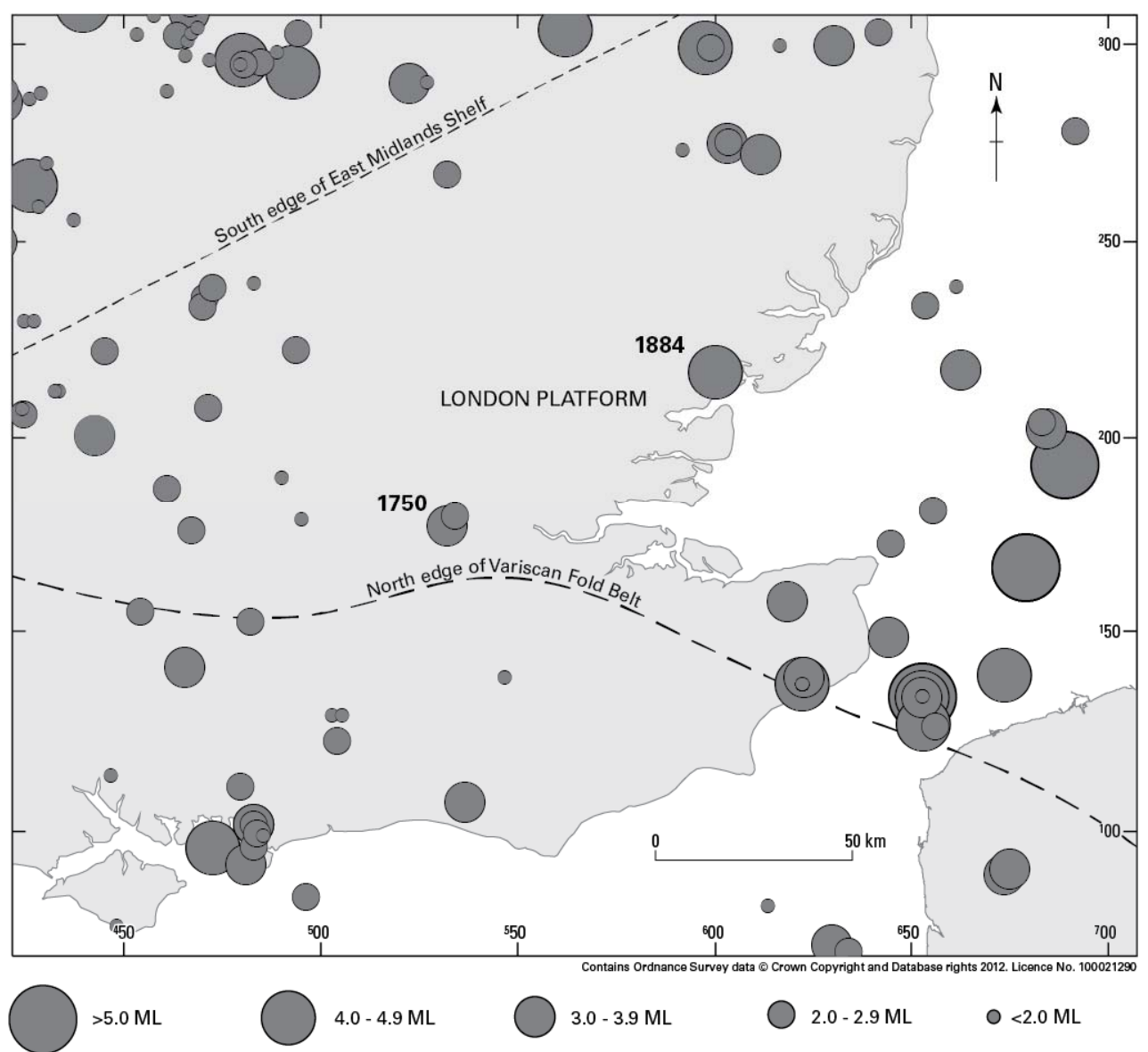

Fig. 3. Recorded earthquakes in south-eastern England

Position of London indicated by M25 orbital motorway. Earthquake information reproduced by permission of the British Geological Survey @ NERC. Compare Musson (2007, fig. 9). 
A.

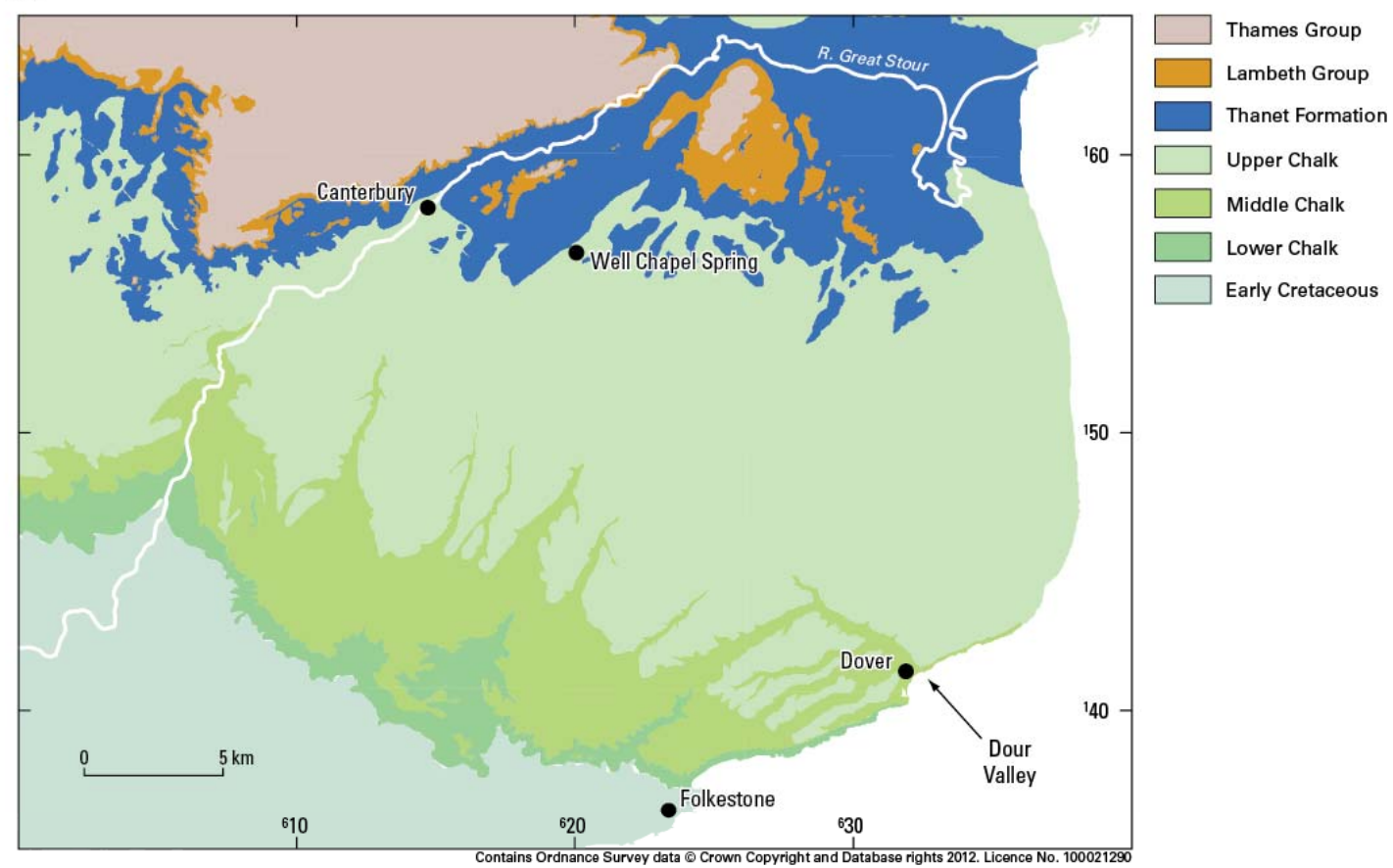

B.

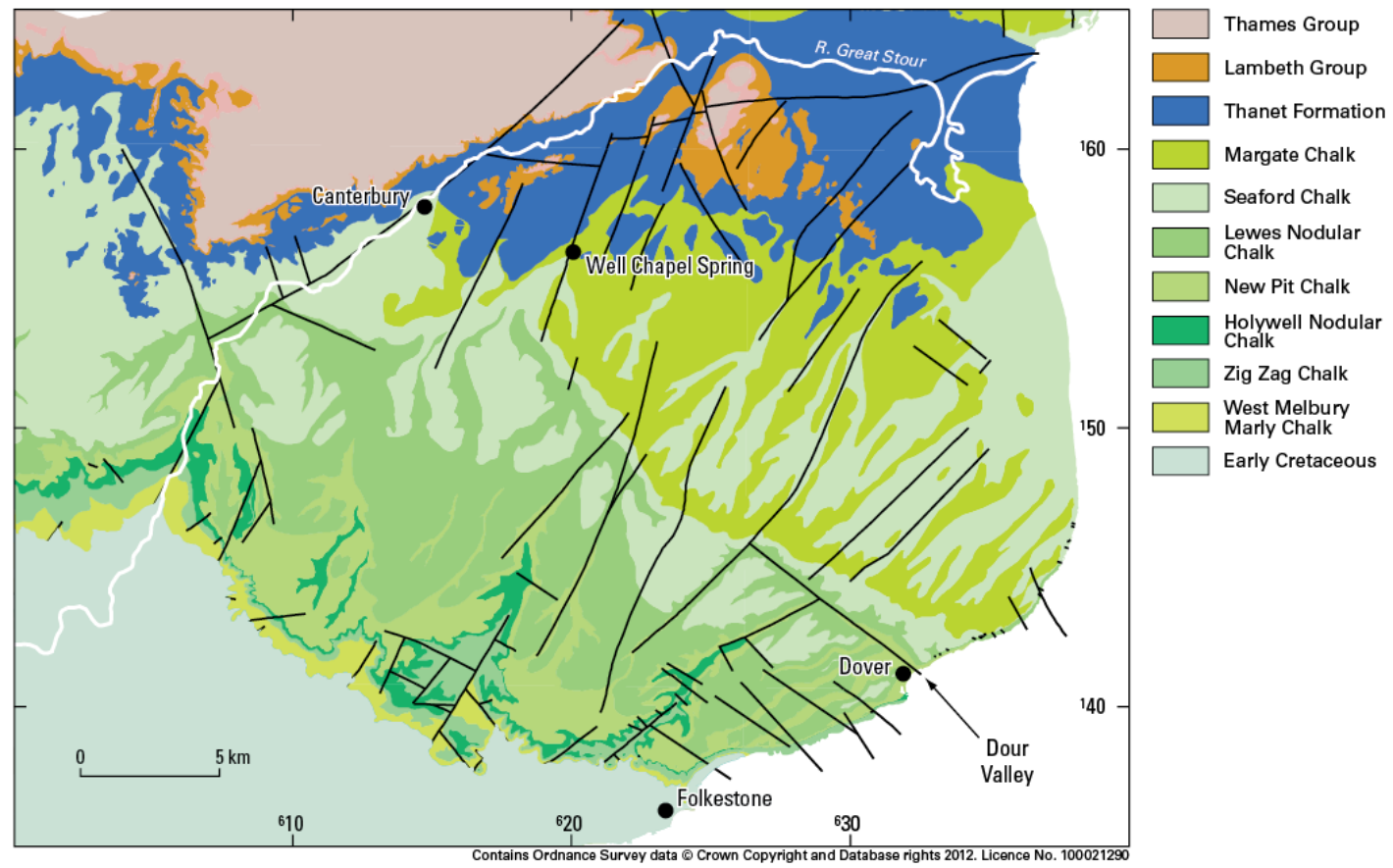

Fig. 4. Bedrock geology of East Kent

A: Original survey using traditional subdivisions of the Chalk Group, as on published paper 1:50 000 scale geological maps

B: Revised survey using modern lithostratigraphic classification of the Chalk Group (Hopson, 2005).

Taken from DiGMapGB-50 (http://www.bgs.ac.uk/data/services/digmap50wms.html). 
A.

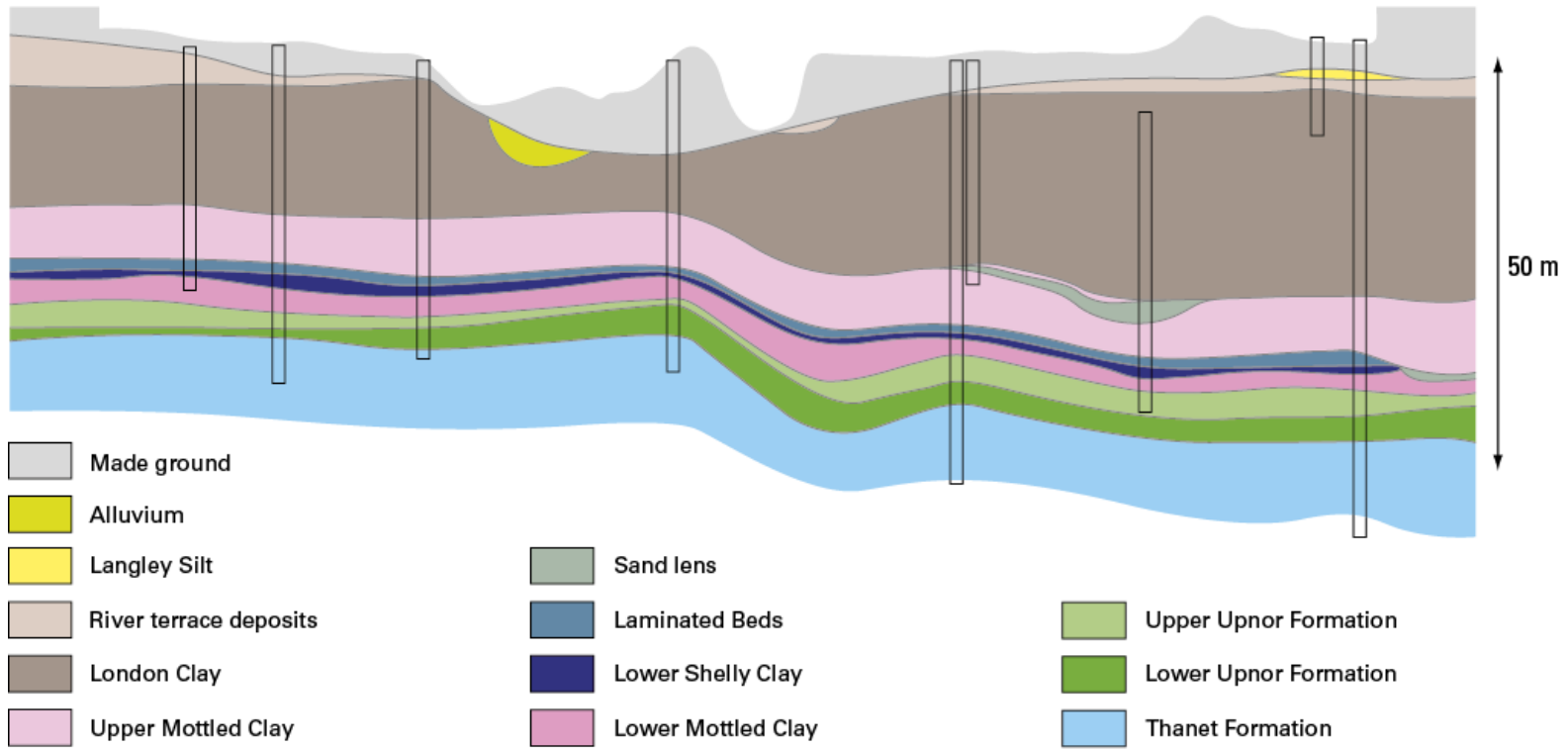

DTM using NextMap Britain ${ }^{\mathrm{M} M}$ dataset covering England, Wales and Scotland. NextMap Britain ${ }^{T M}$ elevation data from Intermap Technologies.

B.

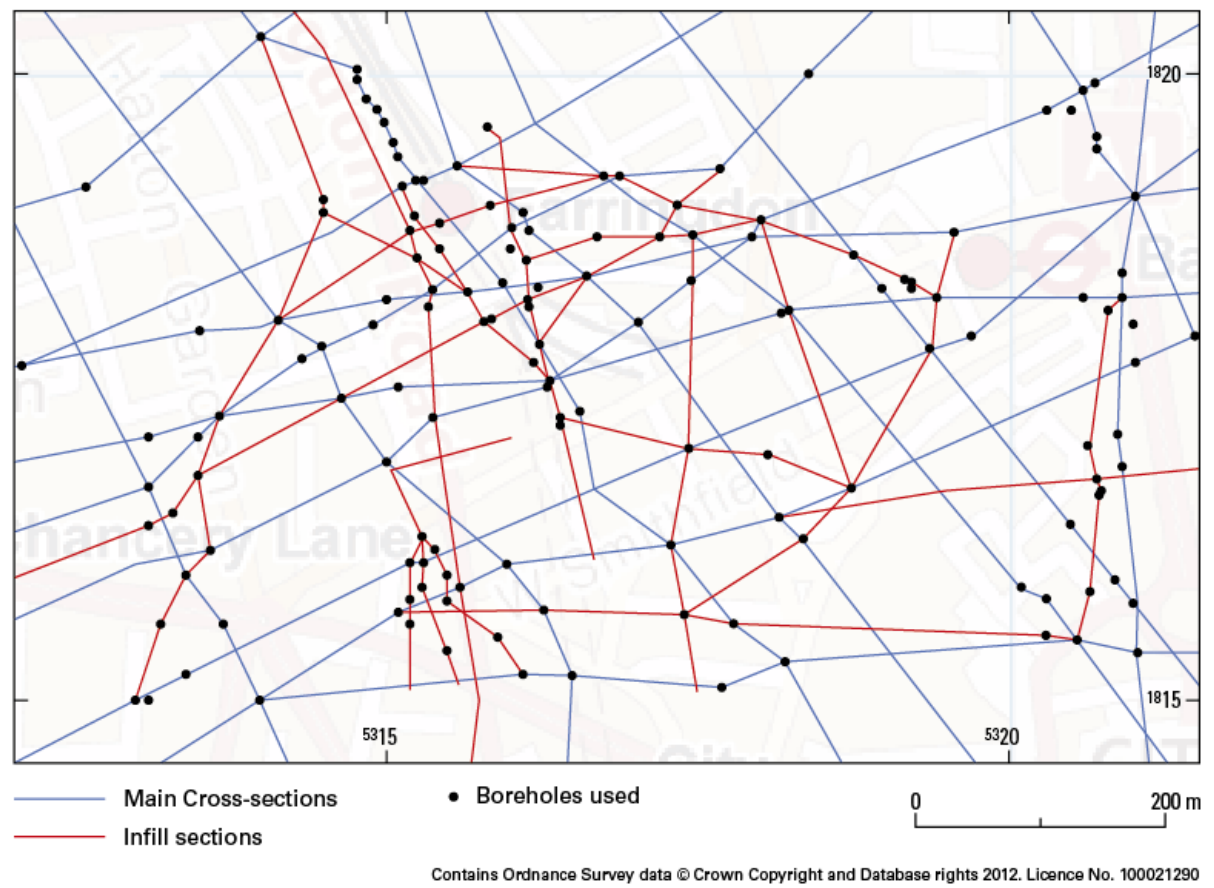

Fig. 5. Development of a 3D geological model in east central London

A: Example of cross-section, with a structural displacement near the mid-point

B: Network of cross-sections for the entire model 
C.

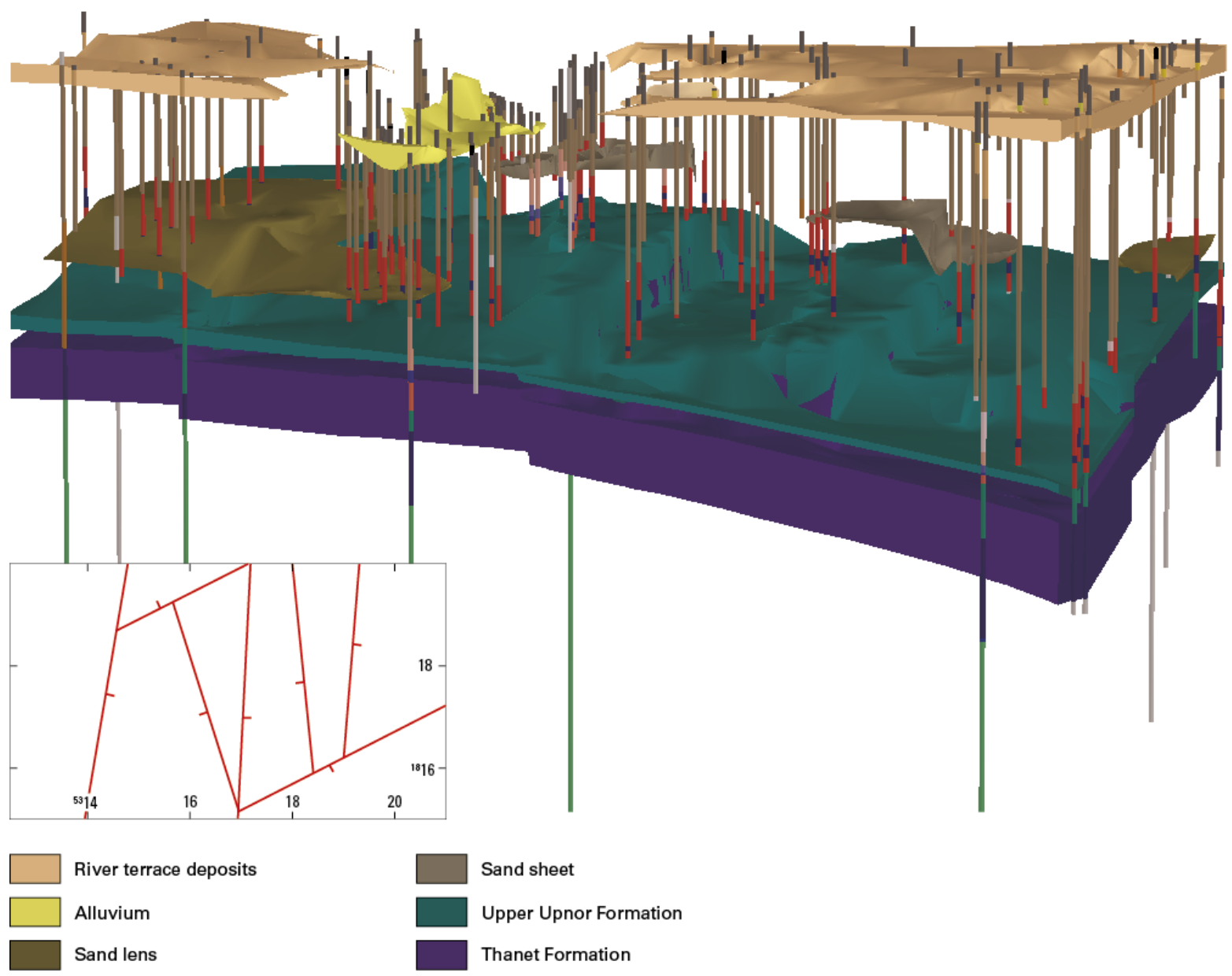

C: Perspective view of completed 3D model, showing only units composed mostly of sand or gravel, with colour-coded 'borehole sticks'. Intervening units above the Thanet Formation are composed mostly of clay. The Chalk Group underlies the Thanet Formation. Inset shows modelled faults, as in Fig. 5D. (Previously published as fig. 4 of Aldiss et al., 2012) 


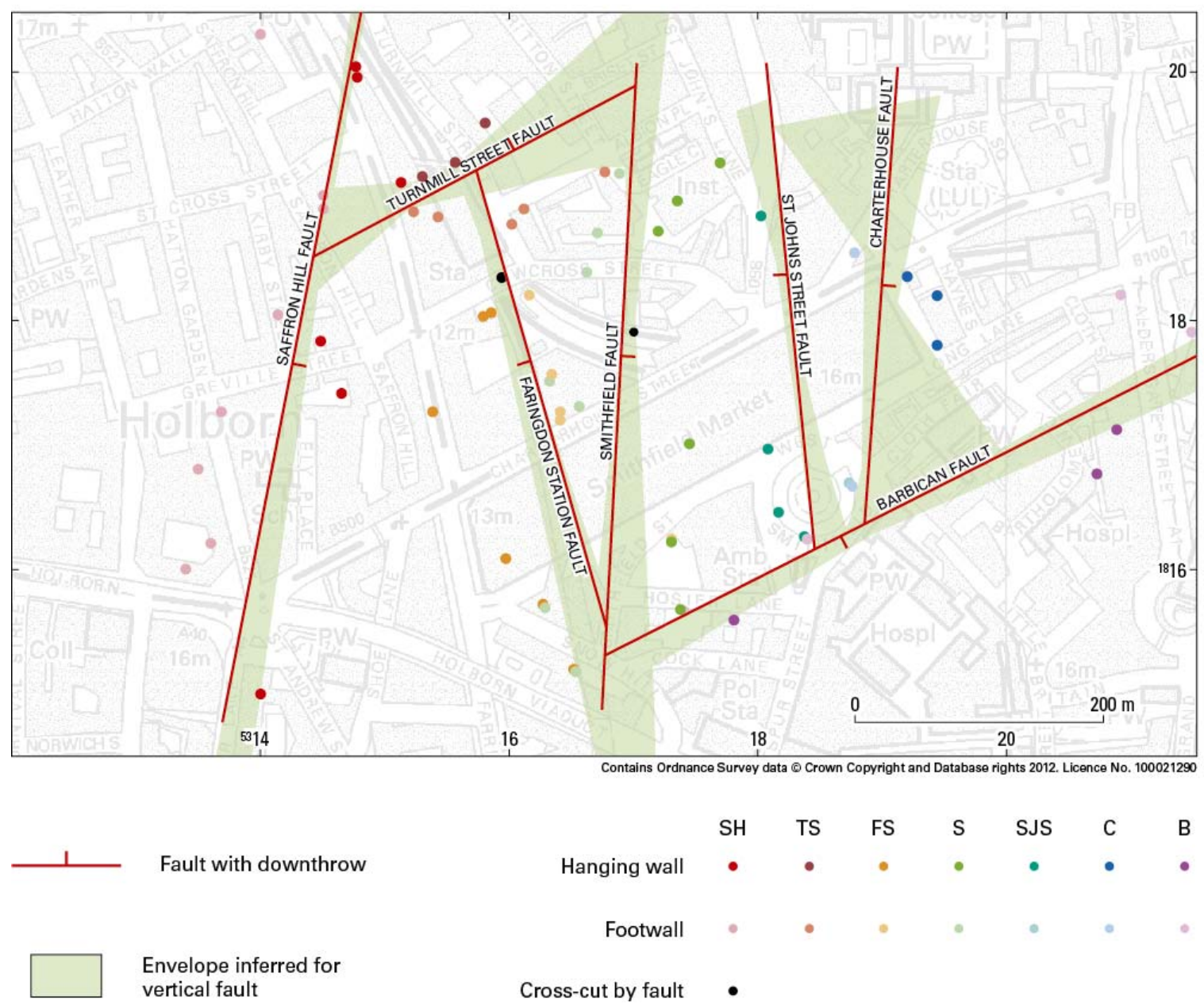

D: Modelled surface traces of inclined normal faults, with extent of vertical fault envelopes and their constraining boreholes. (Previously published as fig. 7 of Aldiss et al., 2012) 
E.
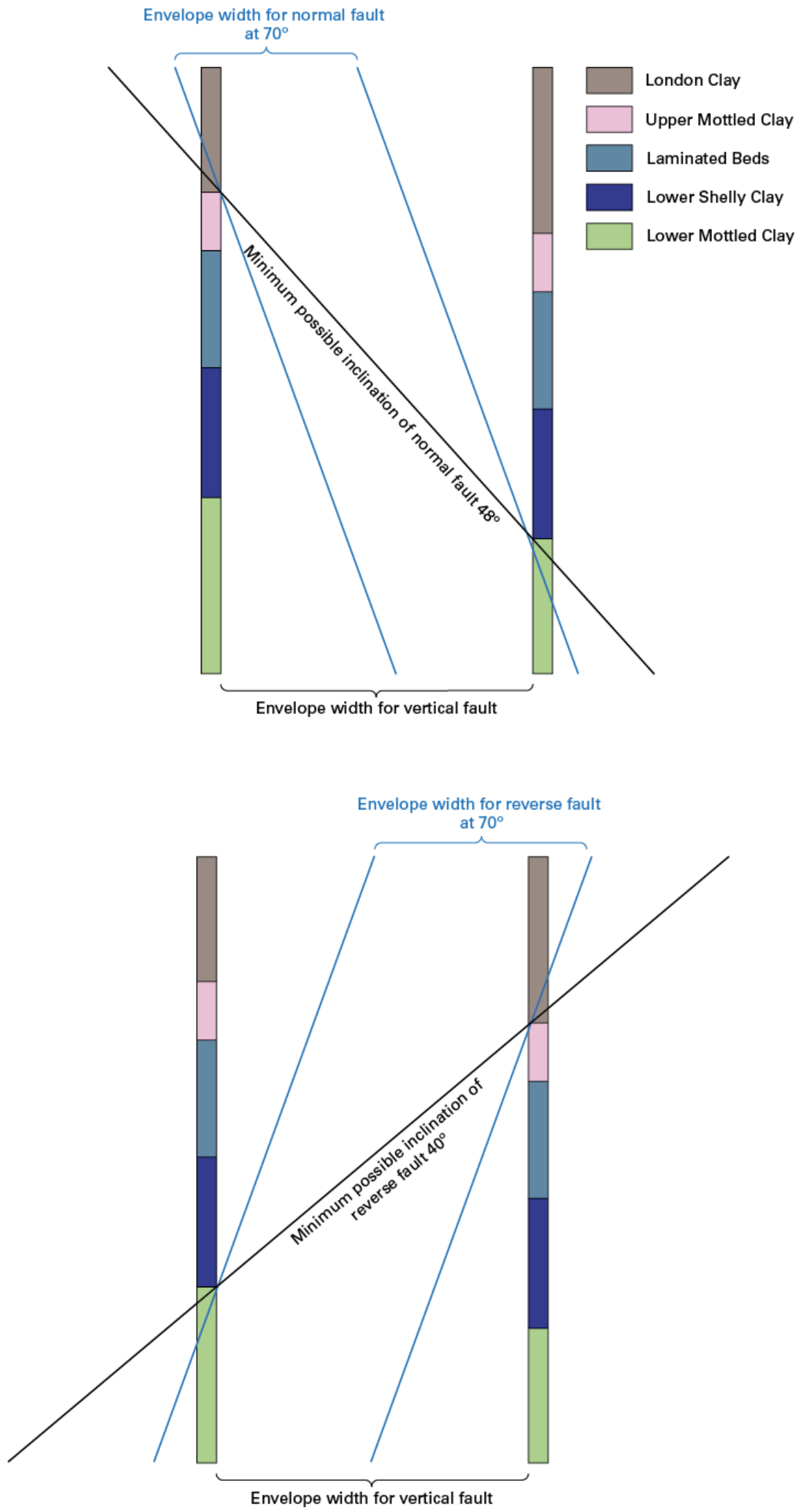

E: Diagrammatic cross-sections to illustrate the theoretical envelopes of a fault constrained by two boreholes 


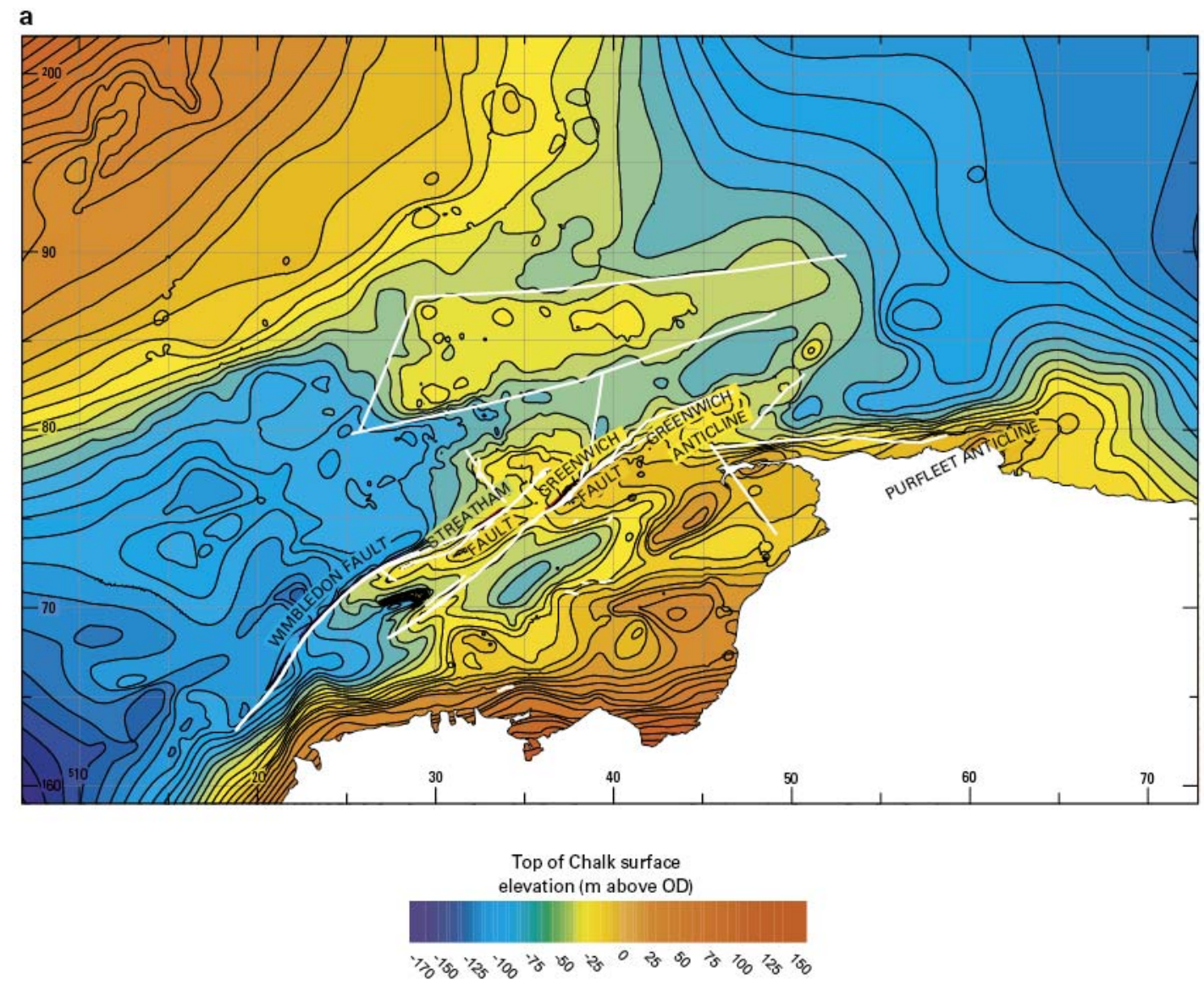

Fig. 6. Surface for top of the Chalk Group from LOCUS model, with selected faults shown as white lines (after Ellison et al., 2004, fig. 45) 
A.

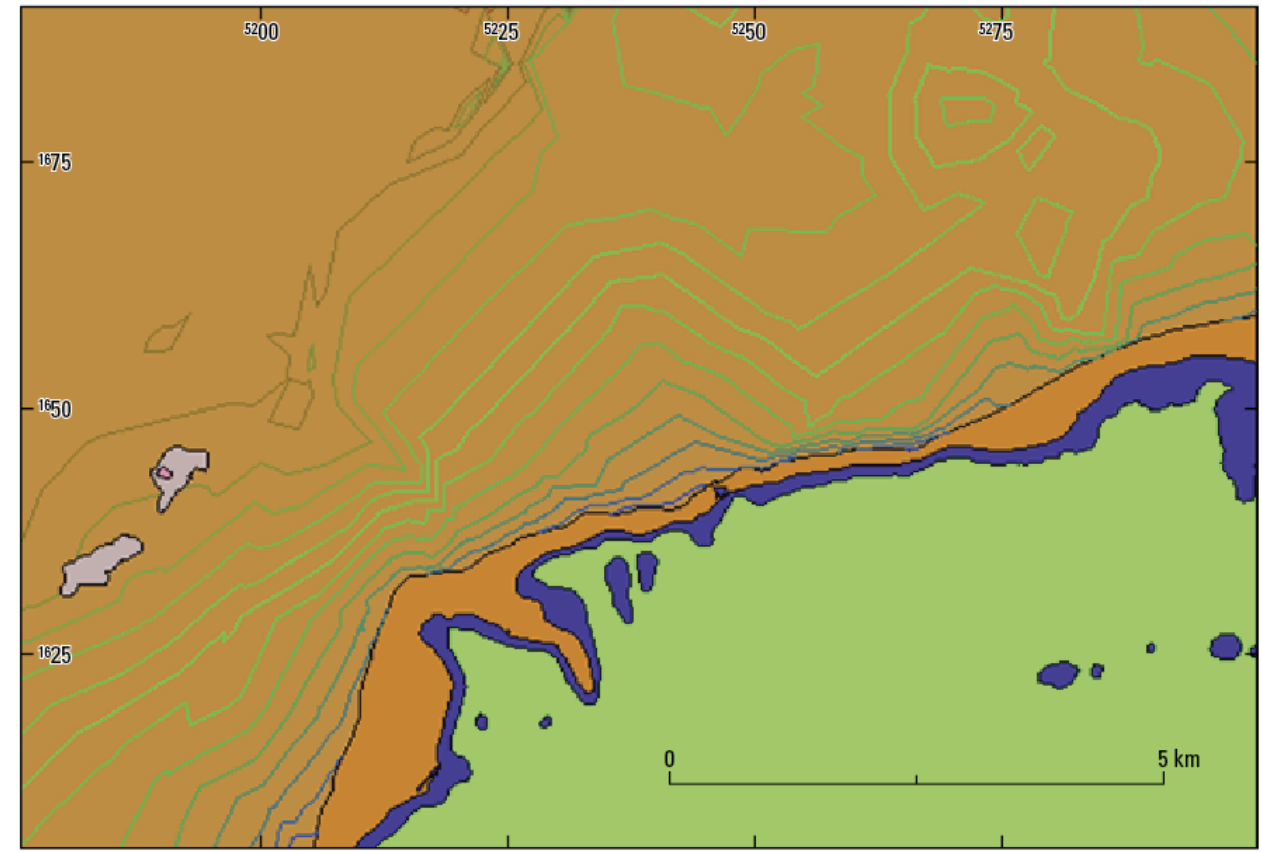

B.

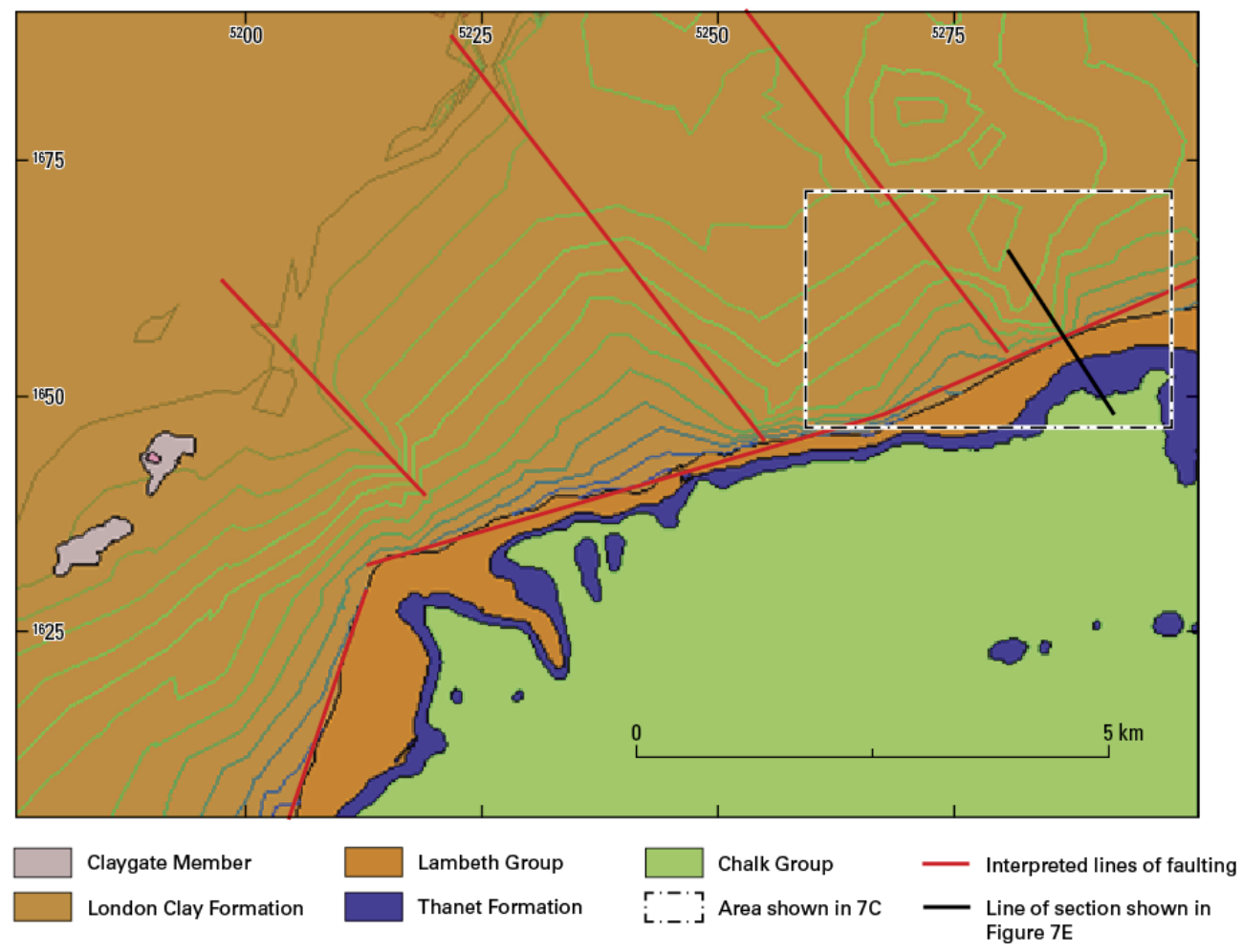

Fig. 7. Probable unmapped faulting in the Hackbridge area, Sutton, south London

A: Bedrock geology with 10 m contours on the base of the London Clay. Taken from GSI3D TM model of London in the Subsurface Viewer ${ }^{\mathrm{TM}}$

B: As 7A but with interpreted lines of faulting.

Taken from GSI3D ${ }^{\mathrm{TM}}$ model of London in the Subsurface Viewer ${ }^{\mathrm{TM}}$ (C) NERC and INSIGHT Gmbh 
C.

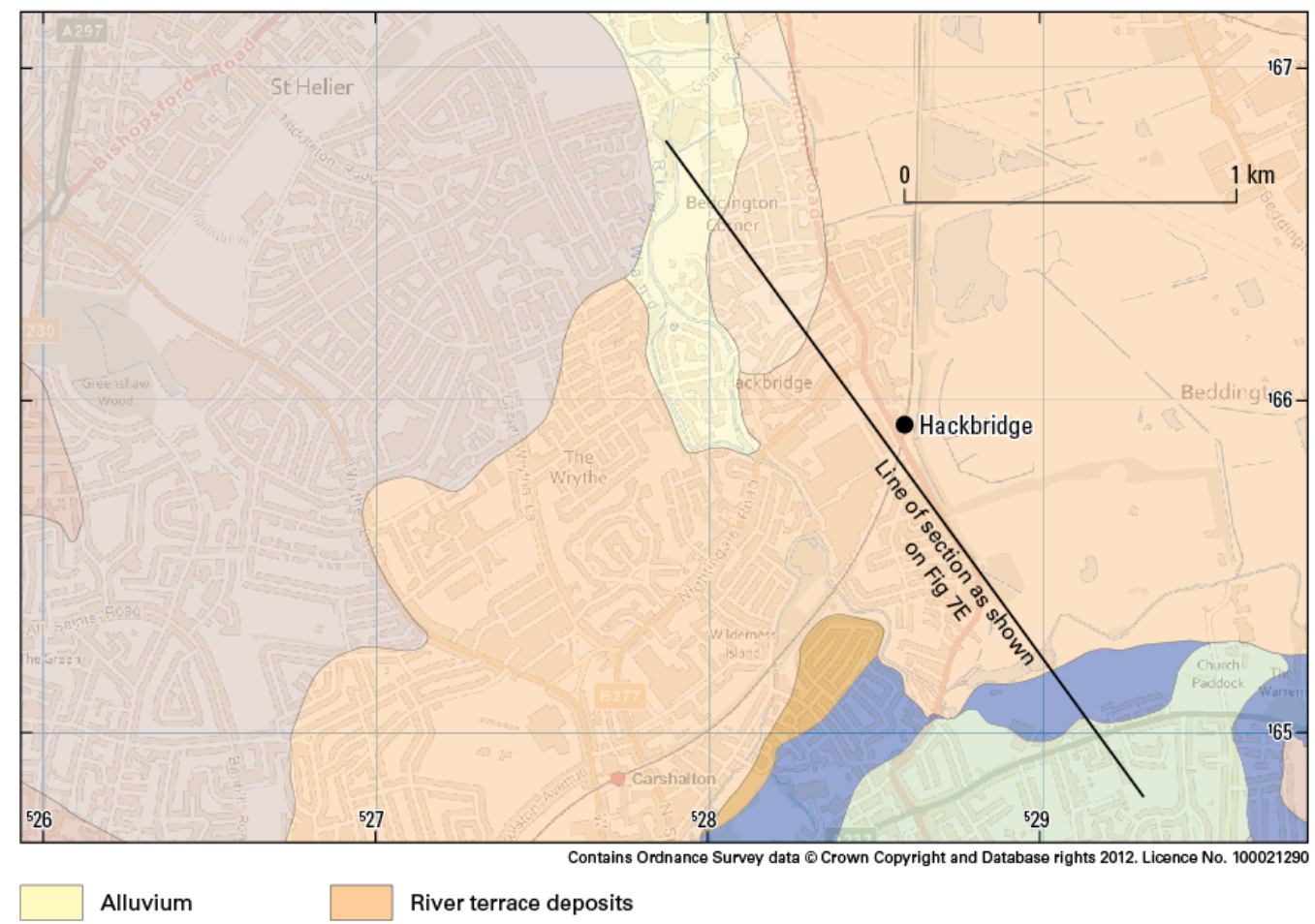

D.

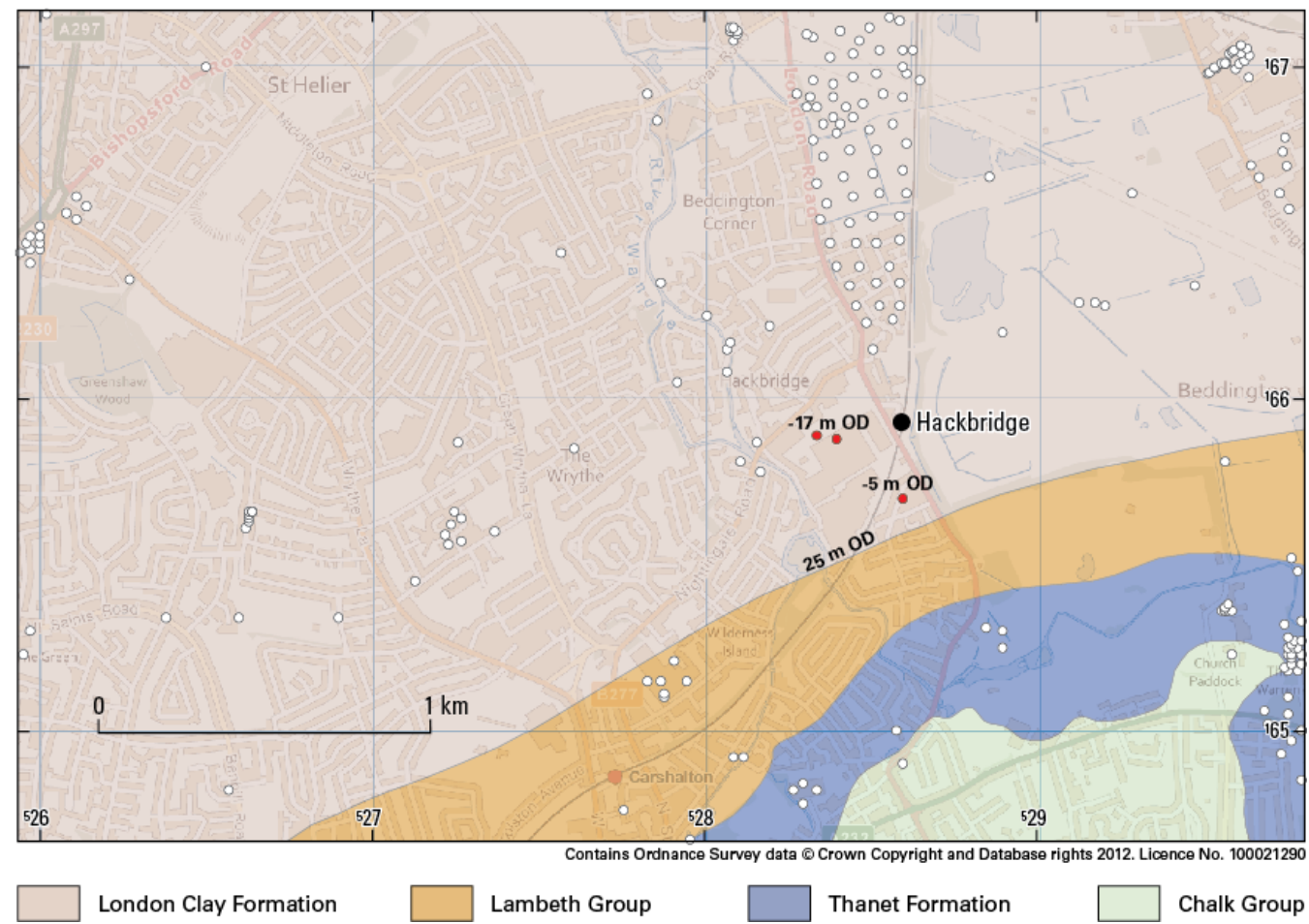

C: Eastern part of Fig. 7A with superficial and bedrock geology. Bedrock is largely covered by river terrace deposits

D: Deep boreholes close to Hackbridge with bedrock geology. Level of base of London Clay indicated. Contact of London Clay and Lambeth Group is very probably faulted. Compare with crosssection in 7E. 
7E.

NW

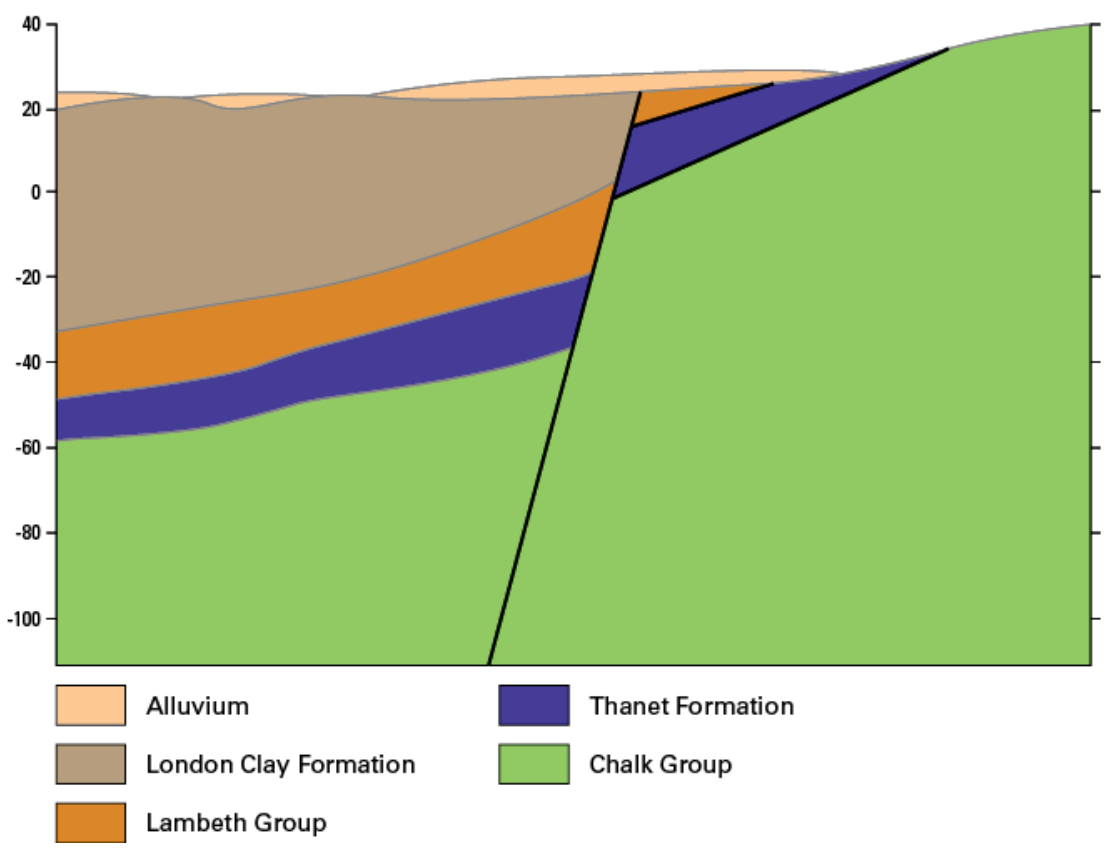

E: Inferred cross-section through Hackbridge, as 7C. Modified from GSI3D TM model of London in the Subsurface Viewer ${ }^{\mathrm{TM}}$ (C NERC and INSIGHT Gmbh 


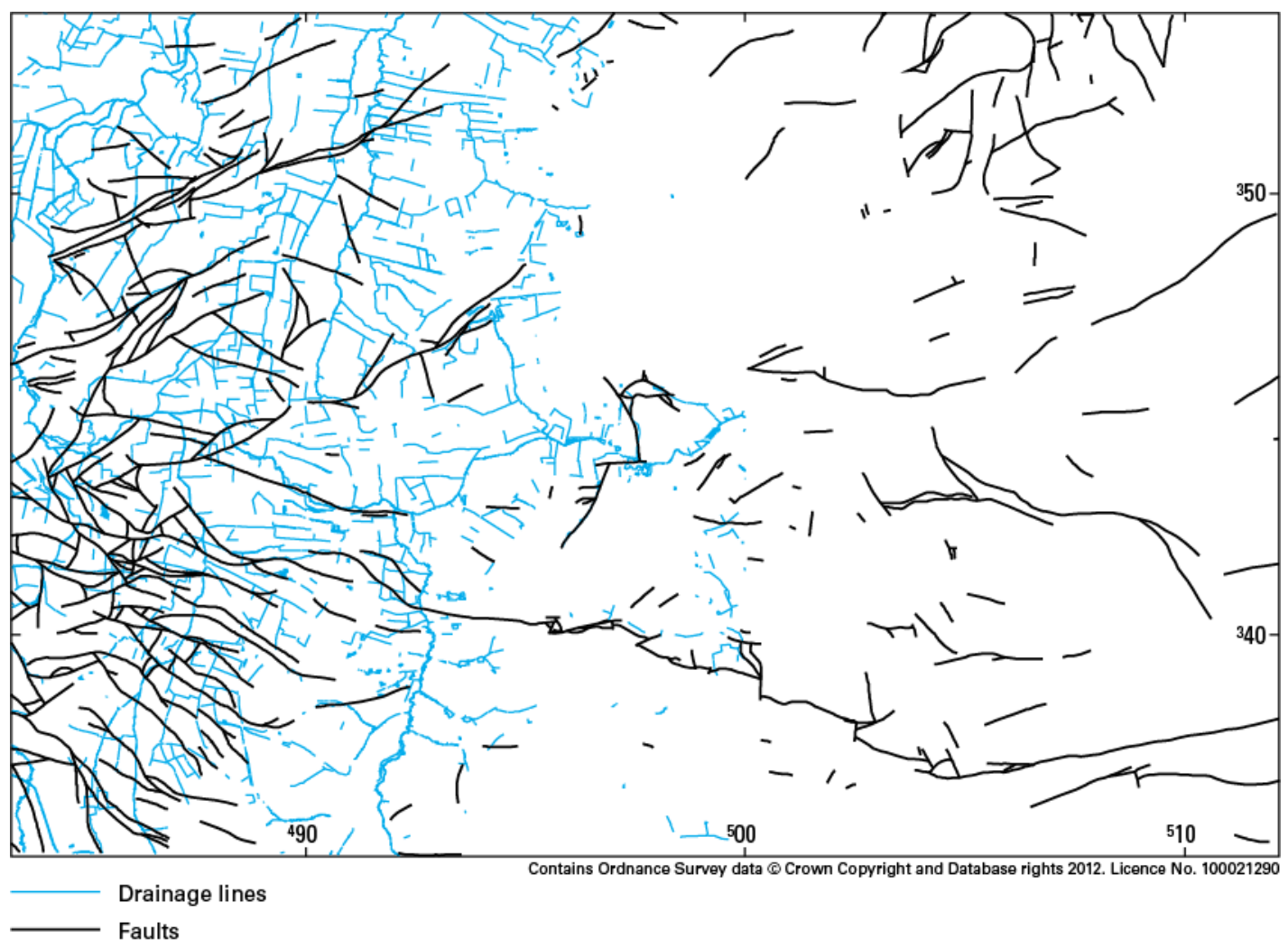

Fig. 8. Fault patterns and drainage in a Jurassic terrain; the Grantham district

Faults from DiGMapGB-50. Drainage lines from Ordnance Survey. The greater density of faults mapped in the west of this area may be due to the presence there of a succession of thin limestone/shale couplets of the Lias Group, which allowed minor faults to be located. 


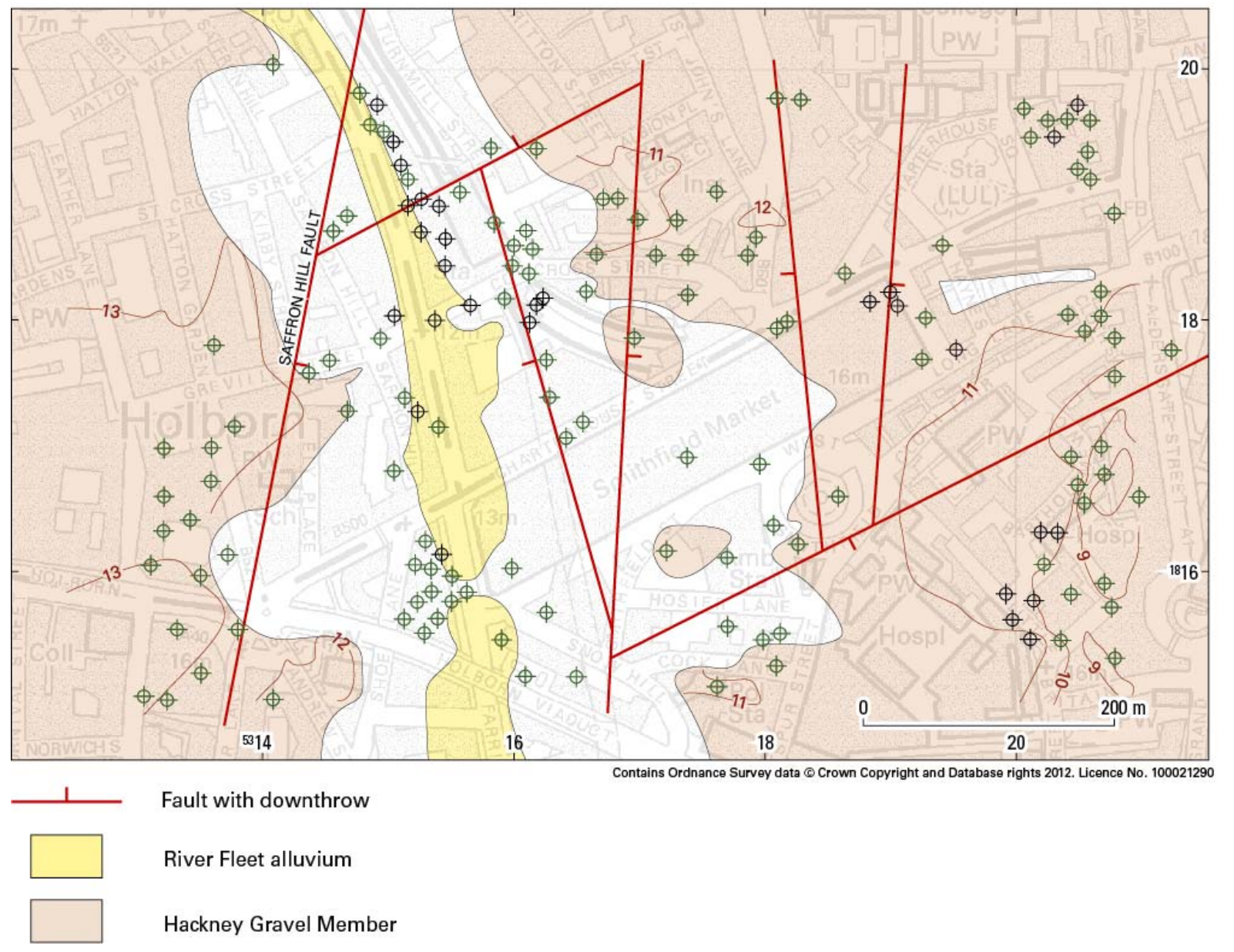

Fig. 9. Hackney Gravel and faults near the River Fleet, east central London

Contours are on the base of the Hackney Gravel at $1 \mathrm{~m}$ vertical intervals. Compare Fig. 5D. 


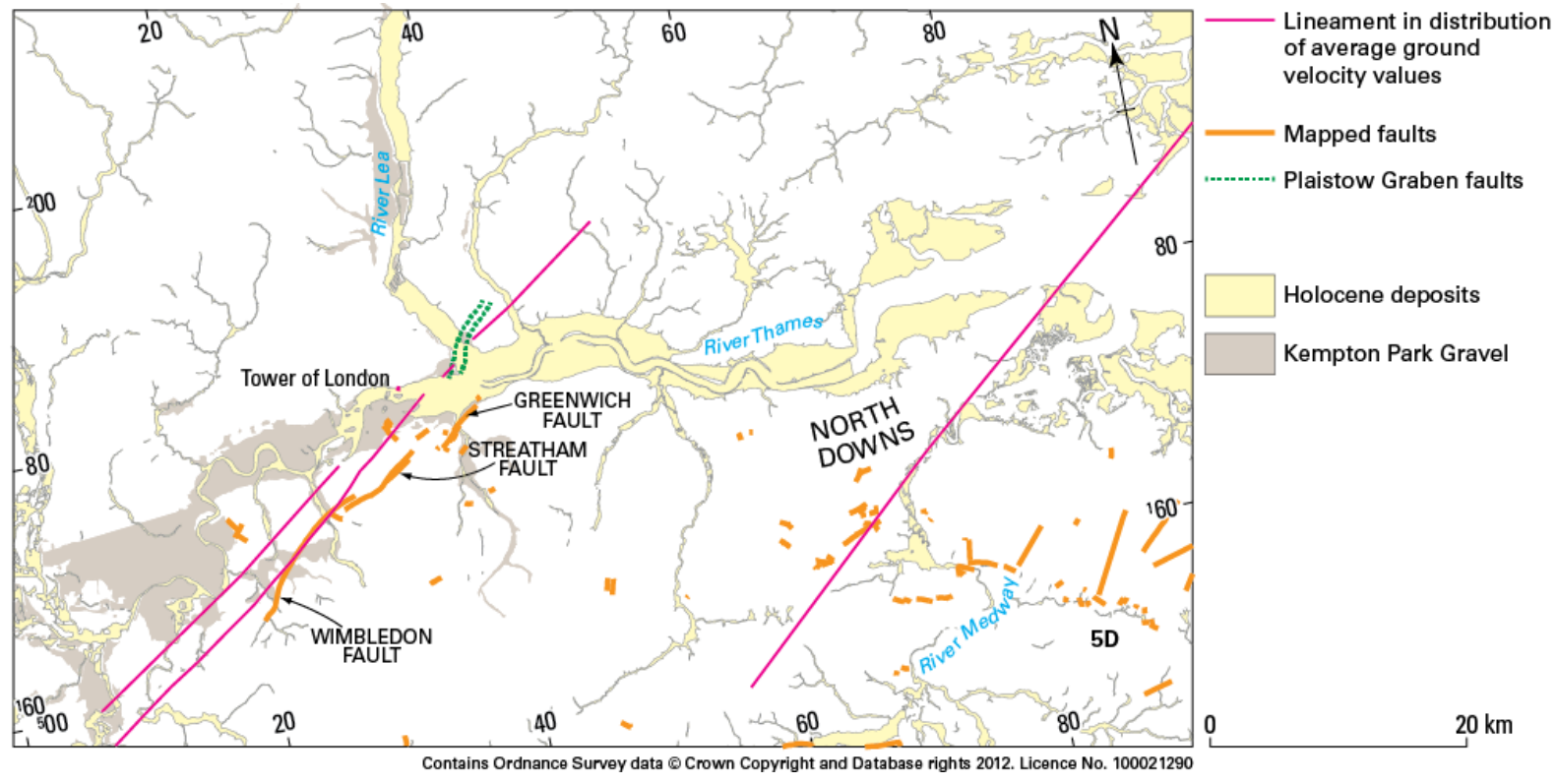

Fig. 10. Relationship between lineaments in vertical ground velocity data and elements of local geology 


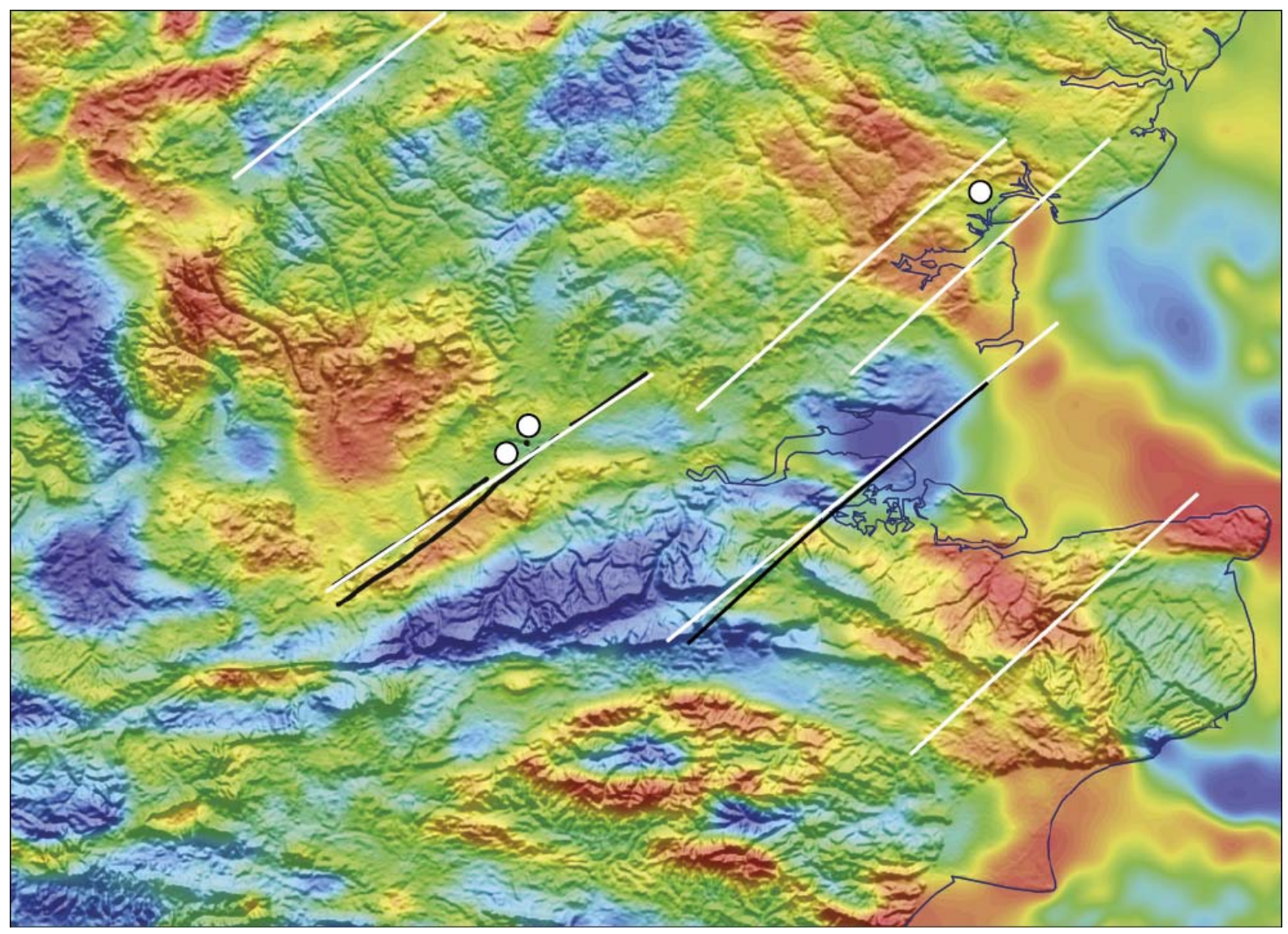

Fig. 11. Bouguer gravity field stripped to base of Mesozoic succession and draped on shaded relief digital terrain model, with selected NE-SW lineaments. Range of values in gravity data is from approximately 0 to $-30 \mathrm{mGal}$. Gravity data processing by B. Chacksfield, BGS. Lineaments in PSI land level change data (Fig. 10) in black. White lineaments in east coincide with fault zones in the Great Stour valley and in the Medway valley. White dots mark inferred epicentres of the three historical earthquakes known in the London (1750) and Essex (1884) areas (cf. Fig. 3). DTM using NextMap BritainTM dataset covering England, Wales and Scotland. NextMap BritainTM elevation data from Intermap Technologies. 